\title{
HYROGEOCHEMISRTY AND RADIOACTIVITY OF GROUNDWATER IN BABA- SIDRI BASINS, SOUTHWEST SINAI, EGYPT
}

\author{
Afandy, ${ }^{1}$ A. H.; Geriesh ${ }^{2}$, M.H.; Eweda, ${ }^{3}$ Sh. A.; Alshami ${ }^{1}$ A.S., and Halim, ${ }^{1}$ Kh.A. \\ 1- Nuclear Material Authority, Cairo, Egypt, \\ 2- Suez Canal Uni. Fac. Sci. Geol. Dep. Ismailia. \\ 3- Zagazig Uni. Fac. Sci. Geology Dept.
}

\begin{abstract}
The hydrogeochemistry investigations through 38 groundwater samples from Baba- Sidri basins have been done. Cations and anions distributions in all water points, as well as their trace element were content $(\mathrm{Co}, \mathrm{Ni}, \mathrm{Pb}, \mathrm{Cu}, \mathrm{Mo}$, F, Mn, As, U, Ra and Th) were discussed. Also, the samples were chemically analysed for uranium $\left(\mathrm{U}^{238}\right)$, thorium $\left(\mathrm{Th}^{232}\right)$ and radium $\left(\mathrm{Ra}^{226}\right)$. The concentration of uranium, thorium and radium in the Quaternary alluvial aquifers is higher than those in Cambro- Ordovician sandstone aquifer and fractured basement aquifer. All ion contents have larger concentration level than the world standards, especially uranium contents in well waters of the study area. Furthermore, the water well is hydraulically connected to the storage drinking tanks, and the radionuclides analysis of samples of drinking tanks recorded the presence of very high uranium contaminant up to $3000 \mathrm{ppb}$ (300 times more the maximum contaminant level). This occurs by the percolation of oxidized waters through the fractured sandstone enriched by uranium minerals, leads to the partially dissolution of the uranium and, subsequently, releasing of uranium species in groundwater.
\end{abstract}

\section{1- INTRODUCTION}

The Paleozoic succession in the southwestern Sinai (up to $320 \mathrm{~m}$ thick) nonconformably overlies the basement complex and in some places is covered by Permo -Triassic basalt sheet and or sill on the top. Salter (1868) reported the first identification of the Paleozoic sedimentary rocks in Sinai. Barron (1907) was the first who can subdivide the Paleozoic section in Sinai. Ball (1916) published the first map of Paleozoic rocks in southwestern Sinai.

Soliman and Abu El Fetouh (1969) subdivided the Paleozoic succession in southwestern Sinai into seven rock units from base to top as follows: Sarabit Elkhadim, Abu Hamata, Adadia, Khaboba, El-Hashash, Magharet El-Maiah and Abu Zarab formations. Weissbrod (1969) gave the term Um Bogma 
Formation to the Middle Carbonate Series and in (1980) he gave the term Abu Thora Formation to the Upper Sandstone Series.

The Mn-Fe ores in the Paleozoic rock were discovered in the $2^{\text {nd }}$ half of the nineteenth century. While the radioactive anomalies were discovered in the middle of the Twentieth century by Abd el Monem et al. (1958). Alshami (2004) found that the gibbsite bearing sediments extends to more than kilometer at Taleat Seleium and Abu Thora area. The study area is located in southwestern Sinai, to the east of Abu Zenima city between latitudes $28^{\circ} 52 \mathrm{~N}$ $\& 29^{\circ} 04^{\prime} \mathrm{N}$ and Longitudes $33^{\circ} 18^{\prime} \mathrm{E} \& 33^{\circ} 25^{\prime}$ ' E (Fig.1).

It is accessible and connected with Abu Zenima and Abu Rudies cities with a good asphaltic roads and car tracks network. Sinai Peninsula belongs to an area lying within the arid belt, which includes the northern part of Africa and extends to southeastern Asia. The mean annual rainfall is generally less than $100 \mathrm{~mm}$. The heavy rainfall during a winter season in Sinai generally occurs between November and January. The highest temperature at summer season in Sinai is in the range of $35^{\circ}-42^{0} \mathrm{C}$. The relative humidity is highest at the coastal plain and decreases in the inland direction from $69 \%$ along the coast to $60 \%$ in the inland areas. The average annual precipitation in southwestern Sinai, which includes the study area, is low (around $25 \mathrm{~mm} / \mathrm{y}$ ). Most of the precipitation occurs during a relatively wet period from November to March. Rains generally begin in November and attain their maximum during the second half of December, January and the first half of February. Heavy rainfall occurs in winter for very short periods and results in torrential floods in the wadies.

\section{2- GEOLOGY OF THE STUDY AREA}

The Paleozoic sedimentary rocks of south Sinai have been studied by several authors of different specializations such as geology, structure, geophysics, hydrogeologic, geochemistry, paleontology, petrography, sedimentology and REEs studies of south Sinai are numerous and diversified (Barron (1907), Ball (1916), Gindy (1961), Soliman and Abu El Fetouh (1969). Weissbrod (1969), El Aassy et al. (1986), Kora (1995), Alshami (1995), El Agami (1996), Abd El Monem et al. (1997), Shata (2002), Alshami (2003), El Aassy et al. (2006), El Aassy et al. (2011) and El -Rayes and Arnous (2015). The study area is covered by Pre- Cambrian igneous rocks, which are unconformably overlies by a thick Paleozoic sequences up to reach about $245 \mathrm{~m}$ (Fig. 2). The Pre-Cambrian rocks are mainly composed of granodiorites and alkali feldspar granites, while the Paleozoic sequence are mainly composed of dominant

varicolored shale, siltstone with claystone, which intercalated with dolostone rocks. The Paleozoic sequences subdivided into seven rocks units from oldest to younger as (Sarabiat El Khadim (19m) of Cambrian age, Abu Hamata 
(21m) of Cambro - Ordovician age, Adadia (125m) of Cambro - Ordovician, Um Bogma (14m) of Early Carboniferous, El Hashash (33m) of Early Carboniferous, Maghareat El Maih (4m) of Early Carboniferous, and Abu Zarab (23m) of Early Carboniferous (Fig.2). The rational to select Abu Zenima area as examine area is related to since the ancient Egyptian time, that the area has been considered as an important locality for some promising ores as copper, manganese, iron, kaolin, glass sands, and recently uranium, Thorium and REEs. All these ores are incorporated in the Paleozoic rocks. Kaolin, coal and white sand are associated with Abu Thora Formation, while $\mathrm{Mn}-\mathrm{Fe}$, copper, uranium and Thorium ores are associated mainly with Um Bogma Formation. Also, it has gibbsite bearing sediments extend to several kilometers.

The Paleozoic succession represents an important rock unit in southwestern Sinai. It is mainly composed of sandstone, shale, dolostone and claystone. These rocks are well exposed at several localities (Fig. 2). The lower sandstone series, comprising Sarabit El Khadim, Abu Hamata and Adadia formations, is well developed at W. Abu Hamata, Gabal Sarabit El- Khadim, Gabal Adadia, Gabal Abu Trifia, Gabal Al Monagah, and W. Nasib.

El - Rayes, Arnous (2015) studied the hydrogeochemistry of W. Baba area. They prove that the groundwater affected by uranium mineralization is associated as a rule with low magnesium content.

Water resources in Sinai Peninsula depend on rainfall, springs and waterbearing formations. The important water-bearing formations in Sinai, as a whole, include fissured basement rocks, Nubian sandstone, Mesozoic and Tertiary carbonates and Quaternary alluvial sediments.

\section{3- HYDROGEOLOGY}

In the study area, Bir (water well) Naseib is the main source for water supply for domestic use. Bir Allouga is relatively small water well, with a depth of $15 \mathrm{~m}$ and represents an additional water source. There is another well located between the previously-mentioned two wells and characterized by it is brackish water.

The hydrological setting of the studied basins mainly affected by the prevailing arid climate and geomorphic setting (El-Shamy, 1983). The desert regions are characterized by scarce rainfall which represents the unique source of recharge to the existing aquifers and when exists, occasionally falls as short heavy storms causing flash flood hazard. The studied basins receive great part of runoff, most which goes to the Gulf of Suez, while the other part evaporates or percolates downward through the pore spaces and/or fractures to feed the different aquifers. 
Thirty-eight (38) water points representing the groundwater of the different aquifers (Fig. 3) represent the distributions of the collected groundwater samples in the studied area.

\section{1- Water - bearing Formations:}

The water- bearing formations that detected in the studied area will be described in the following paragraphs:

\section{1. 1- The Quaternary Alluvial Deposits Aquifers:}

The Quaternary aquifers represent the important water sources in the arid terrains such as Eastern Desert and Sinai, they are exploited in drinking and irrigation purposes because the easy and cheap digging of shallow wells in such aquifers. The alluvial deposits are diversified in their texture and composition along the course of the hydrographic basin. They consist of poorly sorted sands, silts, clays and gravels with boulders and cobbles derived from the exposed rocks.

The thickness of the Quaternary alluvial aquifer in the study area ranges from $8 \mathrm{~m}$ to $13 \mathrm{~m}$. At W. Baba, area fourteen wells are present. Six of them are located at W. Baba itself, (B.1, 2,3,4,5 and 6). Another six wells occur at W. Kharige (Kh.1, 2,3,4,5 and 6) and two wells are recorded at Ramsa area (R.1 and 2). Generally, all the groundwater samples collected in the summer seasons (dry and hot). Quaternary aquifers reflect higher ability for transmitting and sorting water and good groundwater potentialities in west Sinai. The groundwater flow and accumulation in the alluvial aquifer are controlled by the aquifer thickness and the existence of irregularities in relief of the underlying basement rocks such. In addition, the successive resistant dikes dissect the alluvial deposits into several semi-isolated reservoirs. Connection between these reservoirs may take place by the overflow after heavy rainy seasons (Kassem, 1981).

\subsection{2-TheCambro- Ordovician sandstone aquifer:}

The most collected samples of the study area were represented in these Formation Sixteen water points. The Cambro- Ordovician sandstones (Abu Hamata and Adadia Formations) have a wide distribution in the study area. Nine wells in Adadia Formation (Ag.1, 2, 3, 4, 5, At.1, Nb.1 and Sh.1 and 2. Seven in Abu Hamata Formation (S.S. 4, 5, 6, 7, 8, 9 and 10) most wells in W. Nasib (Nb) and Allouga (Ag) were existing in Abu Hamata Formation, while nine wells exist in Adadia Formation.

\subsection{3-ThePrecambrianfracturedbasement aquifer:}

The basement rocks are widely distributed in the study area especially in W. El Shallal, Baba, Seih Sidri and Iqna. They are represented by metagabbro, diorite complex, older and younger granites. Eight (8) wells are tapping this aquifer, one at W. Seih (S.1), one at W. Zobier (Z.1), two at W. Seih Sidri (S.S.1-2), two at W. Shallal (Sha1-2), one at W. Iqna (S.S.3) and one at Bedda locality B.1). The fractures, the dikes and the sinuosity are the main factors 
controlling groundwater occurrences (Aggour et al, 2008). The fractured granites represent the main water bearing Formation in study area. Rocks are generally impermeable except through fractures (faults- joints). El- Shazly et al. (1985) stated that, in igneous and metamorphic rocks porosity occurs primarily in the form of joints and fractured. Joints porosity may be large than $2 \%$ of the total rock volume. On the other hand, the porosity of the weathered igneous and metamorphic rocks may exceed on 10\%, El- Rayes (2004), El Shamy et al. (1889) and El -Shamy, El- Rayes (1992).

\section{4- HYDROGEOCHEMISTRY}

The main objectives of the present study are to determine the chemical characteristics for the groundwater for the existing aquifers to conclude the conditions or the environments of the surrounded rocks. Thirty-eight water samples were collected from the different water wells in the study area (Fig. 3). Eight water samples from the Pre-Cambrian fractured basement aquifer, sixteen water samples from the Cambrian sandstones aquifer and fourteen water samples from the Quaternary alluvial aquifer. The chemical analyses of the collected water samples are listed in tables (1,2 and 3). A complete chemical analysis of the groundwater includes the determination and trace elements contents. The major dissolved components in the groundwater that constitute the bulk of the mineral matters contributing to total dissolved solids (TDS) are cations of Sodium $\left(\mathrm{Na}^{+}\right)$, Potassium $\left(\mathrm{k}^{+}\right)$, Magnesium $\left(\mathrm{Mg}^{++}\right)$, Calcium $\left(\mathrm{Ca}^{++}\right)$, and anions of Chloride $\left(\mathrm{Cl}^{-}\right)$, Sulfate $\left(\mathrm{SO}^{-2}\right)$, Carbonate $\left(\mathrm{CO}_{3}^{-2}\right)$ and Bicarbonate $\left(\mathrm{HCO}_{3}{ }^{-}\right)$. Also, groundwater contains some minor and trace elements such as Lead $\left(\mathrm{Pb}^{+2}\right)$, Cobalt $(\mathrm{Co})$, Uranium (U), Thorium $(\mathrm{Th})$, Copper $(\mathrm{Cu})$, Molybdenum (Mo), Chromium (Cr), (As), Cadmium $\left(\mathrm{Cd}^{+}\right)$, Manganese $\left(\mathrm{Mn}^{++}\right)$and Iron $\left(\mathrm{Fe}^{++}\right)$.

The hydrochemichal properties of groundwater of the study area are discussed here in the below:

\section{1. Salinity distribution:}

Total dissolved salts (TDS) or Salinity include all dissolved, salts ionized and non-ionized, in water and do not include organic materials and gases. Total salinity distribution is represented in (Fig.4) which shows the variation in groundwater salinity. In general, total salinity increases from upstream highlands to the downstream.

The total dissolved salts of the groundwater samples issued from the fractured basements rock aquifers that vary from $342 \mathrm{ppm}$ (Bd.1) to $5800 \mathrm{ppm}$ (Z.1).

The total dissolved salt of the groundwater issued from the Quaternary alluvial aquifers varies from $1810 \mathrm{ppm}$ (Kh.6) to $10470 \mathrm{ppm}$ (B.5). The high TDS values may referred to the dissolution of evaporate minerals enriching the source rocks. 
The total dissolved salts of the groundwater issued from the CambroOrdovician sandstones varies from ppm 307 (S.S.10) to 3995 ppm (Ag.1). The total salinity distribution reveals that the groundwater from the CambroOrdovician sandstone aquifer has lower salinity than those of the fractured basement aquifers and the Quaternary alluvial aquifer. This is because the groundwater flowing through the fractured developed in the sandstone aquifer dissolves very small quantities of the minerals due to their relative insolubility, unless mineralization zone exists. This can be attributed to the following reasons:

1- The longer flow path of groundwater in the Quaternary alluvial aquifers than the basement aquifer. The surface area of contact in alluvial aquifers is more than in the fractured basement rock aquifer. The alluvial sediments have more soluble minerals and individual elements than the basement rocks.

2- The presence of the local sources of pollutions near the water points in the alluvial aquifer (Ghodief et al., 1999).

\section{2. Magnesium $\left(\mathrm{Mg}^{++}\right)$:}

Magnesium derived principally by the weathering of rocks containing ferromagnesium minerals and form some carbonate rocks such as dolomite $\left(\mathrm{MgCO}_{3} \cdot \mathrm{CaCO}_{3}\right)$ and magnesite $\left(\mathrm{MgCO}_{3}\right)$, Figure (5) shows the distribution of magnesium in the different aquifers, the figures shows that:

I) The concentrations of magnesium in the fractured basement aquifer vary from $12.16 \mathrm{ppm}$ (Sha.1) to $145.92 \mathrm{ppm}$ (Z.1).

II) The concentrations of magnesium in the Quaternary alluvial aquifers vary from $48.64 \mathrm{ppm}$ (Kh.6) to $486.4 \mathrm{ppm}$ (B.6).

III) The concentrations of magnesium in the Cambro- Ordovician sandstones aquifer vary from $12.16 \mathrm{ppm}$ (most samples) to $194.56 \mathrm{ppm}$ (Ag.2).

\section{3. Calcium $\left(\mathrm{Ca}^{++}\right)$:}

The main source of calcium in the natural water is the carbonates rocks. Calcium is readily dissolved from rocks rich in calcium bearing minerals, particularly of the carbonate rocks and sulfates minerals such as (Gypsum). Calcium and magnesium are responsible for hardness of the water. According to Hem, (1989), the average content of calcium in some major earth crust is: $22400 \mathrm{ppm}$ in sandstones, $22500 \mathrm{ppm}$ in shale and $27200 \mathrm{ppm}$ in carbonate rocks. Figure (6) represents the distribution of calcium in the aquifers of the study area. It is concluded that:

I) The concentrations of calcium in the fractured basements aquifer vary from $4.08 \mathrm{ppm}$ (Sha.1) to $400.8 \mathrm{ppm}$ (Z.1).

II) The concentrations of calcium in the Quaternary alluvial aquifer vary from $160.32 \mathrm{ppm}$ (Kh.6) to $1282.56 \mathrm{ppm}$ (B.5).

III) The concentrations of calcium in the Cambro- Ordovician sandstones aquifer vary from $20.04 \mathrm{ppm}$ (At.1) to $681.36 \mathrm{ppm}$ (Ag.2). 
4. 4. Sodium $\left(\mathrm{Na}^{+}\right)$:

Sodium is considered as one of the most abundant elements in the earth. Sodium content is almost related to salinity of the groundwater. The source of sodium in natural water is the weathering of $\mathrm{Na}$ - bearing rocks and principally depending on the components of water bearing formation, where sodium may be presented as impurity or as soluble sodium salts. According to Hem (1989), the average content of sodium in some sedimentary rocks is $4850 \mathrm{ppm}$ in shale, $3870 \mathrm{ppm}$ in sandstone and $393 \mathrm{ppm}$ in carbonate rocks. Figure (7) shows the distribution of sodium in the different water bearing aquifers. It shows that:

I) The concentrations of sodium in the fractured basements aquifer vary from $55 \mathrm{ppm}$ (Bd.1) to $1481 \mathrm{ppm}$ (Z.1).

II) The concentrations of sodium in the Quaternary alluvial aquifer varies from $373.33 \mathrm{ppm}$ (Kh.6) to $2000 \mathrm{ppm}$ (B.5).

III) The concentrations of sodium in the Cambro- Ordovician sandstones rock aquifer vary from $55 \mathrm{ppm}$ (S.S.10) to $840 \mathrm{ppm}$ (Ag.1).

\section{5. Potassium content $(K+)$ :}

Potassium is the more abundant element in all sedimentary rocks where these rocks contain relatively high percentage of K- bearing minerals. According to Hem (1989), shale contains 24900 ppm, sandstone 13200 ppm and carbonate $2390 \mathrm{ppm}$ in average. Figure (8) shows the distribution of potassium in the different aquifer of the study area. It shows that's:

I) The concentrations of potassium in the fractured basements aquifer vary from $3.7 \mathrm{ppm}$ (Bd.1) to $16.66 \mathrm{ppm}$ (Sha.1).

II) The concentrations of potassium in the Quaternary alluvial aquifer vary from $7.77 \mathrm{ppm}$ (Kh.6 and 4) to $23.45 \mathrm{ppm}$ (B.5).

III) Cambro- Ordovician sandstone aquifer varies from $3.88 \mathrm{ppm}$ (At.1) to 15.74 ppm (Ag.2).

\section{6. Carbonate and bicarbonate $\left(\mathrm{HCO}_{3}{ }^{-}\right)$:}

Carbonate and bicarbonate ions presented in water are mainly derived from rocks composed mainly of calcium carbonate rocks. The concentration of bicarbonate in water is greatly depending on amount of $\mathrm{CO}_{2}$ in water. The formation of carbonate and bicarbonate is related to the following equation:

$$
\begin{aligned}
& \mathrm{CO}_{2}+\mathrm{H}_{2} \mathrm{O} \text {------------ } \mathrm{HCO}_{3}{ }^{-}+\mathrm{H}^{+} \\
& \mathrm{CaCO}_{3}+\mathrm{H}^{+}-\text {----------- } \mathrm{HCO}_{3}{ }^{-}+\mathrm{Ca}^{++}
\end{aligned}
$$

Figure (9) shows the distribution of bicarbonate in the different aquifers.

I) The concentrations of bicarbonate in the fractured basements aquifer vary from $122 \mathrm{ppm}$ (Sha.1, S.S.2 and S.S.1) to 224 ppm (S.S.3).

II) The concentrations of bicarbonate in the Quaternary alluvial aquifer varies from $152.5 \mathrm{ppm}$ (Kh.5) to $549 \mathrm{ppm}$ (Kh.3).

III) The concentration of bicarbonate in the Cambro- Ordovician sandstones rock aquifers vary from $61 \mathrm{ppm}$ (S.S.10) to $305 \mathrm{ppm}$ (Ag.4). 
With respect to carbonate content of the studied samples, the results of the water analysis indicate that the carbonate is presented in all samples with the same level of 31 ppm.

\section{7. Chloride content $\left(\mathrm{Cl}^{-}\right)$:}

Chloride is the most common major ion in the earth crust. The main sources of chloride are the evaporation processes and dissolution of sedimentary rocks of marine origin, such as shales. The occurrences of the chloride depend on the environmental condition during deposition, where they are present in high concentrations in marine sediments. According to Hem (1989), some sedimentary rocks contain chloride, such as shale $423 \mathrm{ppm}$, sandstone $120 \mathrm{ppm}$ and carbonate $7.1 \mathrm{ppm}$. Figure (10) represents the distribution of chloride in the different aquifers of the study area.

I) The concentrations of chloride in the fractured basements aquifer vary from $56.72 \mathrm{ppm}$ (Bd.1) to $7222.6 \mathrm{ppm}$ (Z.1), which could be attributed to evaporation.

II) The concentrations of chloride in the Quaternary alluvial aquifer vary from 514.02 ppm (Kh.6) to 5643.64 ppm (B.5).

III) The concentrations of chloride in the Cambro- Ordovician sandstone aquifer vary from $35.45 \mathrm{ppm}$ (S.S.10) to $1751.23 \mathrm{ppm}$ (Ag.2).

According to the study of Taylor and Oza (1954) the chloride in groundwater were classified into four classes:

1- Small chloride content $<200$ ppm that's include (S.S.6- S.S.7- S.S.9S.S.10- Ag.5- Nb.1- At.1- Sh.1- Sh.2- Bd.1).

2- Medium chloride content ranged between 200 and $500 \mathrm{ppm}$ that is include (Sha.1- S.S.2- S.S.2- S.S.3- S.S.4- S.S.5- S.S.8- Ag.3- Ag.4- S.1).

3- High chloride content ranged from 500 to $1000 \mathrm{ppm}$ that is including (Kh.1- Kh.4- Kh.6- Sha.2- S.S.1).

4- Very high chloride content with $>1000 \mathrm{ppm}$ that is include (Z.1- Ag.1Ag.2- Kh.2- Kh.3- Kh.5- R.1- R.2- B.1- B.2- B.3- B.4- B.5- B.6)

\section{9. Sulfate content $\left(\mathrm{SO}_{4}^{--}\right)$:}

The main source of sulfate is generally gypsum and anhydrite dissolution. It also forms as a result of the oxidation of sulfide ores. Gypsum is easily dissolved in water at ordinary temperature where it gives about $1500 \mathrm{ppm}$ sulfate concentration at the saturation point. Sulfate is widely distributed in reduced form both in igneous and sedimentary rocks as sulfide. Industrial discharges and atmospheric precipitation can also add a considerable amount of sulfate to surface water. Under anaerobic conditions, bacteria convert sulfate to hydrogen sulfide. Figure (11) represents the distribution of sulphate in the different aquifers of the study area.

I) The concentrations of sulfate in the fractured basements aquifer vary from $86.4 \mathrm{ppm}$ (Bd.1) to $742 \mathrm{ppm}$ (Z.1). 
II) The concentrations of sulfate in the Quaternary alluvial aquifer vary from 164 ppm (Kh.4) to $2286 \mathrm{ppm}$ (Kh.1).

III) The concentration of sulfate in the Cambro- Ordovician sandstones aquifer varies from $72.48 \mathrm{ppm}$ (S.S.10) to $765 \mathrm{ppm}$ (Ag.2).

\section{8. Ion dominance:}

The ion dominance within the studied water samples of the different aquifers are arranged in a decreasing order of abundance of the main soluble ions as following (Schoellers, 1962):

Anions: They are accumulated in the following groups:

1) $\mathrm{Cl}>\mathrm{SO}_{4}>\mathrm{HCO}_{3}$ : that is includes most the water samples.

2) $\mathbf{C l}>\mathbf{H C O}_{3}>\mathbf{S O}_{4}$ : that is includes samples of (Kh.2- Kh.3- Kh.4- R.2S.S.3- S.S.5- Sh.1- Sh.2- Sha.1).

Cations: They are accumulative in the following group:

1) $\mathbf{N a}>\mathbf{C a}>$ Mg: that is includes (main group in different aquifers).

2) $\mathbf{N a}>\mathbf{M g}>$ Ca: that is includes (Sha.1- Bd.1- B.1- B.6)

3) $\mathbf{C a}>\mathbf{N a}>$ Mg: that is includes (S.S.3- S.S.9- Ag.2).

\section{9. Classification of groundwater:}

\section{Pipers Classification Diagram:}

The trilinear diagram is one of the more widely graphical method used for classification of natural waters (Piper, 1953). This type of classification is based on the percentage equivalent per millions of cations and anions. Pipers diagram defines groundwater genesis and the characters of groundwater through the relationship among the alkali $(\mathrm{Na}, \mathrm{K})$, alkali earths $(\mathrm{Ca}, \mathrm{Mg})$, alkalinity $\left(\mathrm{CO}_{3}, \mathrm{HCO}_{3}\right)$ and salinity $\left(\mathrm{SO}_{4}, \mathrm{Cl}\right)$. Piper's diagrams for the groundwater of the quaternary alluvial aquifer (Fig. 12), indicates that all the samples have the same origin and of the same aquifer. On the other hand both of the Cambro- Ordovician aquifer (Fig. 12) and the fractured Precambrian basement aquifer (Fig. 14) shows that the groundwater samples do not have the same conditions, that indicate existence of two types of water and a type of mixing in between is existed causing dilution and or contaminations due to the increasing of trace elements ranges than the world standards.

\section{9. 2. Schoellers Diagram:}

On the other hand, the Schoellers diagram is linear diagram based on a system developed in part by the French investigator Schoellers, (1962). Schoellers diagrams for the quaternary alluvial aquifer shows that all the groundwater samples lay in one pattern, indicating that it has the same origin (Fig. 15) where the Cambro - Ordovician aquifer (Fig. 16)

and Fractured Precambrian basement aquifer (Fig. 17) show that all the groundwater samples are separated into two patterns according to their sources that reflect the different water type. 


\section{10. Trace element distributions:}

\section{10. 1. Copper $\left(\mathrm{Cu}^{++}\right)$:}

Copper are relatively insoluble, so little copper found in natural water. The toxicity of copper depends upon the hardness and $\mathrm{pH}$ of water and therefore, it is more toxic in soft and low alkalinity water (Jones, 1964).

The toxic level of copper in aquatic samples varies from 1 to $1.5 \mathrm{mg} / \mathrm{l}$ (Hem, 1986). Copper is an essential element in human metabolism, but it can cause anemia, disorders of bones, connective tissue and liver damage at excessive level. So, drinking water shouldn't have more than $1 \mathrm{mg} / 1 \mathrm{Cu}^{++}$(Bouwer, 1978). Figure (18) represents the distribution of copper in the different aquifers. The copper value in the Cambro- Ordovician sandstones aquifers range from $2.35 \mathrm{ppb}$ (Ag.2) to $73.28 \mathrm{ppb}$ (S.S.5), while it ranged in the quaternary alluvial aquifer from $1.29 \mathrm{ppb}$ (B.2) to $99.2 \mathrm{ppb}$ (Kh.5) and varying in the fractured Precambrian basement aquifer from36 ppb (Bd.1) to $107.8 \mathrm{ppb}$ (S.1).

\section{10. 2. Lead $\left(\mathrm{Pb}^{++}\right)$:}

Lead is one of the main trace elements that occur in natural water when accumulated, lead causes poison impacts to human and animals. Lead concentration in water is limited and controlled by the solubility restrictions. The lead toxicity appears to be greater in soft water than hard water (Pickering and Henderson 1960). Lead concentration in rain and river water ranges from $0.1 \mathrm{ppm}$ or more in areas that subjected to substantial air pollution that down to $0.001 \mathrm{ppm}$ or less in more remote areas (Lazarus et al. 1970). Lead limit in drinking water is $0.05 \mathrm{mg} / \mathrm{l}$ (W.H.O standard 1963). Figure (19) shows the distribution of lead in the different aquifers of the study area. The lead value in the Cambro- Ordovician sandstones aquifer range from $4.85 \mathrm{ppb}$ (Ag.3) to $34.89 \mathrm{ppb}$ (Sh.2), while it ranges in the quaternary alluvial aquifer from $10.6 \mathrm{ppb}$ (Kh.4) to $29.4 \mathrm{ppb}(\mathrm{Kh} .2)$ and varied in the fractured Precambrian basement aquifer from $3.49 \mathrm{ppb}$ (Sha.1) to $32.8 \mathrm{ppb}$ (S.S.3).

\section{10. 3. Cadmium (Cd++):}

Generally, cadmium exists in zinc bearing minerals such as sphalerite and is recovered from some copper ores during smelting and refining. It is rarely found in natural water. Cadmium is sometimes toxic if its concentration exceeds $0.01 \mathrm{mg} / \mathrm{l}$ (Hem, 1986). The effects of increasing in human body cadmium are kidney damage, destruction of testicular tissue as well as destruction of red blood cells. Figure (20) shows the distribution of cadmium in the different aquifers in the study area. The cadmium value in the CambroOrdovician sandstones aquifers range from $10.62 \mathrm{ppb}$ (S.S.8) to $612.46 \mathrm{ppb}$ (S.S.5), while it ranged in the quaternary alluvial deposits from $9.56 \mathrm{ppb}$ (B.1) to $21.2 \mathrm{ppb}$ (Kh.5) and varying in the fractured Precambrian basement aquifer from $10.2 \mathrm{ppb}$ (Z.1) to $18.26 \mathrm{ppb}$ (S.S.3). 
4. 10. 4. Cobalt $\left(\mathrm{Co}^{++}\right)$:

As shows at table (6) the cobalt values in the Cambro- Ordovician sandstones aquifer ranges from $2.62 \mathrm{ppb}$ (At.1) to $27.63 \mathrm{ppb}$ (S.S.10), while they ranged in the quaternary alluvial aquifer from $8.2 \mathrm{ppb}$ (Kh.3) to $22.6 \mathrm{ppb}$ (R.1) and varying in the fractured Precambrian basement aquifer from $2 \mathrm{ppb}$ (S.1) to $16.98 \mathrm{ppb}$ (S.S.2). (Figure 21).

\section{10. 5. Chromium $\left(\mathrm{Cr}^{++}\right)$:}

The chromium values in the Cambro- Ordovician sandstones aquifers ranges from $13.2 \mathrm{ppb}$ (Sh.1) to $44.69 \mathrm{ppb}$ (S.S.5), while it ranged in the quaternary alluvial aquifer from $16.76 \mathrm{ppb}$ (B.3) to $25.7 \mathrm{ppb}$ (Kh.6) and varied in the fractured Precambrian basement aquifers from $15.3 \mathrm{ppb}$ (Sha.2) to $31.2 \mathrm{ppb}$ (Bd.1). (Figure 22).

\section{10. 6. Arsinic $\left(\mathrm{As}^{++}\right)$:}

The arsinic value in the Cambro- Ordovician sandstones aquifers ranges from $27.14 \mathrm{ppb}$ (Ag.2) to $242.2 \mathrm{ppb}$ (Ag.4), while it ranged in the quaternary alluvial aquifer from $16.9 \mathrm{ppb}$ (Kh.4) to $301.1 \mathrm{ppb}$ (B.4) and varying in the fractured Precambrian basement aquifers from $77.3 \mathrm{ppb}$ (Z.1) to $242.2 \mathrm{ppb}$ (Sha.1). (Figure 23).

\section{10. 7. Manganese $\left(\mathrm{Mn}^{++}\right)$:}

Manganese value in the Cambro- Ordovician sandstones aquifer ranges from $44.9 \mathrm{ppb}$ (Ag.4) to $2.7 \mathrm{ppb}$ (S.S.6), while it ranged in the quaternary alluvial aquifer from $406.8 \mathrm{ppb}$ (B.2) 1.7to $\mathrm{ppb}$ (Kh.1) and varying in the fractured Precambrian basement aquifers from $12 \mathrm{ppb}$ (Z.1) to $0.51 \mathrm{ppb}$ (S.1). (Figure 24).

\section{10. 8. Iron $\left(\mathrm{Fe}^{++}\right)$:}

Abundant source of iron exists in the earth's crust. Some of the important minerals and mineral groups that contain large amount of iron are pyroxenes, amphiboles, magnetite, pyrite, biotite and garnets. The weathering of these minerals releases large amounts of iron, which are usually converted to the relatively insoluble and stable iron oxides. The common form of iron in the groundwater is the soluble ferrous iron $\left(\mathrm{Fe}^{+2}\right)$. Corrosion of well casing and other pipes may also contribute iron to the groundwater. Bacterial activity could increases iron concentration in groundwater. If $\mathrm{pH}$ of groundwater is below 3, the iron should occur in the ferric state $\left(\mathrm{Fe}^{+3}\right)$ but above this $\mathrm{pH}$ ferric iron may be present as a complex compounds. If the Ec is not too high, water contains ferrous iron (Hem and Cropper, 1959). The presence of iron in drinking water leads to a metallic taste. So, the recommended maximum concentration of iron in drinking water is $0.3 \mathrm{mg} / \mathrm{l}$. Iron value in the CambroOrdovician sandstones aquifers range from $1291.6 \mathrm{ppb}$ (S.S.9) to $4.95 \mathrm{ppb}$ (Ag.3), while it ranged in the quaternary alluvial aquifer from $939.6 \mathrm{ppb}$ (Kh.6) to $65.3 \mathrm{ppb}$ (B.3) and varied in the fractured Precambrian basement aquifer from $20.2 \mathrm{ppb}$ (Sha.1) to $400.8 \mathrm{ppb}$ (S.1), Fig. (25). 


\section{11. Radioactivity of groundwater:}

The radioactivity of the groundwater is generally attributed to the penetration of water through the fractured anomalous country rocks. The uranium content in the world mineralized aquifers is $100-460 \mathrm{ppb}$, (Judson and Osmend 1955). Fix (1956) notes that in the uraniferous areas, uranium content in the groundwater ranged from $20-200 \mathrm{ppb}$ and ranged typically from $15-400$ $\mathrm{ppb}$. Uranium mines and uranium in surface water ranging from $1-10 \mathrm{ppb}$ as general in uraniferous area. Denson et al. (1956) stated that the mineralized aquifers contain $10-250 \mathrm{ppb}$ uranium.

In the present study thirty eight groundwater samples were chemically analysis for uranium $\left(\mathrm{U}^{238}\right)$, thorium $\left(\mathrm{Th}^{232}\right)$ and radon $\left(\mathrm{Ra}^{226}\right)$, (Tables. 6, 7and 8).

\section{11. 1. Uranium $\left(\mathrm{U}^{238}\right)$ :}

The concentration of uranium in the different aquifers (Tables. 7, 8 and 9) can be graphically represents in Figure (26):

I) The concentration of uranium in the fractured basements aquifer vary from $1824 \mathrm{ppb}$ (Sha.2) to $385.6 \mathrm{ppb}(\mathrm{Bd})$ with an average of $934.37 \mathrm{ppb}$.

II) The concentration of uranium in the Quaternary alluvial aquifer varies from $3336 \mathrm{ppb}$ (B.5) to $679.4 \mathrm{ppb}$ (B.1) with an average of $1382.8 \mathrm{ppb}$.

III) The concentration of uranium in the Cambro- Ordovician sandstone aquifer varies from $1684 \mathrm{ppb}(\mathrm{Nb})$ to $472.1 \mathrm{ppb}$ (S.S.6) with an average of $981.20 \mathrm{ppb}$.

\section{11. 2. Thorium $\left(\mathrm{Th}^{232}\right)$ :}

The distribution of thorium in the different aquifers (tables 7, 8 and 9) can be illustrates as show in figure (27):

I) The concentrations of thorium in the fractured basements aquifer are not defined because thorium is not soluble in water in general.

II) The concentration of thorium in the Quaternary alluvial aquifer varies from $2.23 \mathrm{ppb}$ (Kh.3) to $1.54 \mathrm{ppb}$ (R.1) with an average of 1.88 .

III) The concentration of thorium in the Cambro- Ordovician sandstone aquifer varied from $2.88 \mathrm{ppb}$ (Ag.3) to $1.67 \mathrm{ppb}$ (Sh.1).

\section{11. 3. Radium $\left(\mathbf{R a}^{226}\right)$ :}

The distribution of radium in the different aquifers (Tables 7, 8 and 9) can be illustrated as following (Figs. 28 and 29):

I) The concentration of radium in the fractured basements aquifer varies from $0.06 \mathrm{~Bq}(1.5 \mathrm{pci})$ in $(\mathrm{SS} 3-\mathrm{S})$ to $0.01 \mathrm{~Bq}(0.33 \mathrm{pci})$ in $(\mathrm{Z}-\mathrm{Sha} 1)$ with an average of $0.0387 \mathrm{~Bq}(1.03 \mathrm{pci})$.

II) The concentration of radium in the Quaternary alluvial aquifer vary from $0.12 \mathrm{~Bq}(3.37 \mathrm{pci})$ in $(\mathrm{Kh} .5)$ to $0.02 \mathrm{~Bq}(0.47 \mathrm{pci})$ in $(\mathrm{Kh} .6)$ with an average of $0.077 \mathrm{~Bq}(2.098 \mathrm{pci})$. 
III) The concentration of radium in the Cambro- Ordovician sandstone aquifer that varies from $0.13 \mathrm{~Bq}(3.57 \mathrm{pci})$ in $(\mathrm{At})$ to $0.01 \mathrm{~Bq}(0.26 \mathrm{pci})$ in (S.S.5) with an average of $0.057 \mathrm{~Bq}(1.55 \mathrm{pci})$.

\section{SUMMARY AND CONCLUSIONS}

The Paleozoic succession in the southwestern Sinai (up to $320 \mathrm{~m}$ thick) nonconformably overlies the basement complex and is covered by PermoTriassic basalt sheet and or sill on the top. The Paleozoic succession in the study area composed of Sarabit El Khadim, Abu Hamata, Adadia, Um Bogma, El Hashash, Magharet El Maih and Abu Zarab Formations.

The area under study comprises three main aquifers, the Quaternary alluvial, Cambro-Ordovician sandstones and Precambrian fractured basement aquifers. All cations $(\mathrm{Mg}, \mathrm{Ca}, \mathrm{Na}$ and $\mathrm{K})$ and anions $\left(\mathrm{Cl}, \mathrm{SO}_{4}\right.$ and $\left.\mathrm{HCO}_{3}\right)$ maximum permissible limits are larger than the world standards.

All the trace elements $(\mathrm{Cu}, \mathrm{CO}, \mathrm{Cd}, \mathrm{Cr}, \mathrm{Ni}, \mathrm{As}, \mathrm{Pd}, \mathrm{Mn}$ and $\mathrm{Fe}$ ) maximum permissible limits are larger than the world standards for all elements, especially uranium contents in drinking water wells digged in the area. Uranium recorded very high contaminant up to $3000 \mathrm{ppb}$ (300 times more the maximum contaminant level). The anions dominance in most samples were $\mathrm{Cl}$ $>\mathrm{SO}_{4}>\mathrm{HCO}_{3}$, where the dominance cations were $\mathrm{Na}>\mathrm{Ca}>\mathrm{Mg}$.

The water wells located at $\mathrm{W}$. Baba are more contaminated than other one. It is recommended to not use as drinking water for human's activities and even for animals.

\section{REFERENCES}

Abdel Monem, A.A., El Aassy, I.E., Hegab, O.A., El Fayoumy, I.F. and El Agami.N. L.(1997): Gibbsite, Uranium and copper mineralizatio n, Um Bogma area, southwestern Sinai, sedimentology of Egypt, vol.5, p.117-132.

Aggour, T.A. and Gomaa, M.A., (2008): Hydrogeological and hydrgeochemical studies in Wadi Baba and Sidri, SW. Sinai. Egypt. Annals Geol. Surv. Egypt. V. xxx, pp 497-528

Aita, S.K. (1996): Geological, mineralogical and geochemical studies on radioactive anomalies of the Paleozoic sediments of Um Bogma area, west central Sinai, Egypt, M.Sc. Thesis, Fac. Of Sci. Cairo.Univ.

Alshami, A.S. (1995): Studies on geology and uranium occurrences of some Paleozoic rocks, Wad Allouga area, Sinai, Egypt. M.Sc. Thesis, Faculty of Science, Zagazig University, $156 \mathrm{p}$.

Alshami A.S. (2003): Structural and lithologic controls of uranium and copper mineralization in Um Bogma environs, south Western Sinai, 
Egypt. Ph.D. Thesis, Faculty of Science, Mansoura University, Egypt. $148 \mathrm{p}$.

Ball, J. (1916): The geography and geology of west central Sinai, Egypt. Surv. Dept. Cairo $219 \mathrm{pp}$.

Barron, T. (1907): The topography and geology of the peninsula of Sinai (Western portion). Egypt. Surv. Dept. Cairo, 241 pp.

Bouwer, H., (1978): Groundwater hydrology. McGraw- Hill Inc., USA, PP. 339-368.

Chebotarev, I., (1955): Metamorphism of natural waters in the crust of the earth. Inter. Geochem. Cosmochem. Acta, 8, 22.

Denson, N., Zeller, H., and Setephans, J., (1956): Water sampling as a guide in the search for uranium deposits and its use in evaluating wide spread volcanic units as potential source beds for uranium.U. S. Geol. Surv. Profess. P. 300, P. 637.

El Agami, N.L. (1996): Geology and radioactivity studies on the Paleozoic rock units in the Sinai Peninsula Egypt Ph.D.

El-Aassy, i.E.; Botros, N.H; Abdel razik, A; Sherif, H; Al Moafy, A., Atia, K., El Terb, R., El-Shami, A. S (1986): Report on the prospection and proving of some radioactive occurrences in west central Sinai, Egypt. Internal Rept., Nuclear Materials Authority (NMA), Cairo.

El-Assey, I.E., Ahmed, F.Y., Shata, A.E., Mohammed, G.A., Al Shami. A.S., Gabr, M.M. and Rabboh, A.A. (2006): New resources of rare earth elements in Sinai, Egypt.7Th inter. Conf. on Geochemistry, Fac.Sci. Alex.Univ, Alex., Egypt, 6-7 Sept. 2006; V.III, p. 177-184.

El Aassy, I.E., El Galy, M.M., Nada, A.A., El Feky, M.G., Abd El Maksoud, T.M., Talaat, S.M., and Ibrahim, E.M., (2011): Effect of alteration processes on the distribution of radionuclides in uraniferous sedimentary rocks and their environmental impact, Southwestern Sinai, Egypt. J. Radioanal. Nucl. Chem., 289: 173- 184.

El-Rayes, A.E. (2004): Use of lineament analyses and joint measurements as guides for drilling high yield water wells in the basement aquifer of South Sinai, Egypt. J. petroleum and Mining Engineering, 7 (1). 67-76.

El-Rayes, A.E. and Arnous, M.O. (2015): Anovel approach in hydrgeochemical exploration for uranium mineralization: an example from West Central Sinai, Egypt, ACTA Geologica Sinica, Vol. 89 No. 4 pp. 1801- 1840.

El-Shamy, I. Z., (1983): On the hydrology of west central Sinai. Egypt J. Geol., 27 (1- 2): 93-105.

El-Shamy T.I.Z., El-Ghawaby M.A. and El-Rayes A.E. (1989): Geologic factors affecting groundwater occurrences in the Basement rocks of Saint Katherine area, Sinai. Proc. $2^{\text {nd }}$ conf. Geol. Sinai. Develop. Ismailia. 2732. 
El-Shamy I.Z. and El-Rayes A.E. (1992): Hydrologic assessment of Saint Catherine area, South Sinai. Proc. $3^{\text {rd }}$ conf. Geol. Sinai Develop, Ismailia. 71- 76.

El-Shazly, M.M., Mohamed, S.S., Abd-Alatif, T.A., Misak. R.F. and Mabrouk, M.A., (1985): Groundwater potential of St. Katherine Monastery environs. Sinai, Egypt. J. Geol., 29, No. 1-2, pp. 89- 100.

El-Sharkawi, M.A., El-Aref, and Abdel Motelib, A. (1990): Manganese deposits in a Carboniferous paleokarst Profile, Um Bogma region, west central Sinai, Egypt. Mineralium Deposita, 25: 343- 354.

Fix, P.F., (1956): Hydrogeological exploration for uranium U. S. Geol Surv. Profess. Papers 300, pp. 667.

Ghodief, K., Dragon, K. and Gorski, J., (1999): Groundwater quality in the Arabian-Nubian shield, Mount Sinai, Egypt. Geologos 4 Conf., Poznan. Poland, PP. 29- 46.

Gindy, A.R. (1961): Radioactivity and Tertiary Volcanic Activity in Egypt: Econ. Geol., 56. 5 57-568.

Hem, J.D., and Cropper, W.H., (1959): Survey of ferrous- ferric chemical equilibrium and redox potentials. U.S. Geol. Surv. Water supply paper, No. 1459-A, $31 \mathrm{pp}$.

Hem, J.D., (1986): Study and interpretation of the chemical characteristics of natural water. U.S. Geol. Surv. Water supply paper No. 1473, pp. 1-363.

Hem, J.D., (1989): Study and interpretation of the chemical characteristics of natural water, Second Ed. U. S. Geol. Surv., water supply 2254, third printing, $264 \mathrm{pp}$.

Jones, J.R., (1964): Fish and river pollution. London, Butterworth.

Judson, S., and Osmand, J.K., (1955): Radioactivity in groundwater and surface water. Am. J. Sci. 253, pp, 104.

Kassem, 1981: Hyrogeologic studies in Wadi Feiran, South Western Sinai, Egypt. M.Sc. Thesis. Suez Canal Univ. Fac. Sci. Geol. Dep. Ismailia, $181 \mathrm{p}$.

Kora, M. (1995): Carboniferous macrofouna from Sinai, Egypt. Journal of Africa Earth science, vol.20, No.1, p.37-51.

Lazarus, (1970): Lead and other metal ions in U.S. Precipitation. Environmental Sci. and Technology, Vol.4, pp. 5558.

Pickering, Q.H. and Henderson, C., (1960): The aqutetoxicity some heavy metals to different species of warm water fishes. International Journal of Air- water pollution, Vol. 10, pp. 453- 463.

Piper, A.M., (1953): A graphic representation in the geochemical interpretationof groundwater analysis: American Geophysical Union Tranaction, Vol. 25, and pp 914- 923. 
Schoeller, H., (1962): Geochemie des beaux souterraines. Rev. De I. Institute Francais du petrole, Vol. 10, pp. 230- 244.

Shata, A.E. (2002): Geological and geochemical studies on uranium and thorium of selected basal sandstones exposures in southern Sinai, Egypt. Mansoura Univ. D. Ph. Thesis, 189 p.

Soliman, S. M. and Abu El- Fetouh, M. (1969): Petrology of the Carboniferous Sandstone in west central Sinai. J. Geol. Univ. A. R., 13/2, p. 61-143.

Taylor, G. G. and Oza, M.M., (1954): Geological survey of the India. Bull. Series B. o. 45, 29 p.

Weissbrod, T. (1969): The Paleozoic outcrops in south Sinai and theircorrelation with those of southern Israel, in the Paleozoic of Israel, and the adjacent countries. Geol. Surv. Israel. Bull. No. 47, pt. 2, v. 2, $32 \mathrm{p}$. 
Table (1): Results of chemical analysis of grounwater of the Quaternary Alluvial aquifer.

\begin{tabular}{|c|c|c|c|c|c|c|c|c|c|c|}
\hline \multirow{2}{*}{$\begin{array}{l}\text { Well } \\
\text { No. }\end{array}$} & \multirow[t]{2}{*}{ Code } & \multirow[t]{2}{*}{ TDS } & \multicolumn{4}{|c|}{ Cations } & \multicolumn{4}{|c|}{ Anions } \\
\hline & & & NA++ & $\mathbf{K}^{+}$ & $\mathrm{Ca}^{++}$ & $\mathrm{Mg}^{++}$ & $\mathrm{Cl}^{-}$ & $\mathrm{SO}_{4}^{--}$ & $\mathrm{CO}_{3}^{--}$ & $\mathrm{HCO}_{3}{ }^{---}$ \\
\hline 1 & B.1 & 4607 & 1050 & 13.88 & 200.4 & 291.84 & 2183.7 & 642 & 31 & 183 \\
\hline 2 & B. 2 & 4015 & 910 & 13.88 & 400.8 & 97.28 & 1946.2 & 426 & 31 & 183 \\
\hline 3 & B. 3 & 3468 & 813 & 12.03 & 280.56 & 97.28 & 1534.9 & 446 & 31 & 244 \\
\hline 4 & B. 4 & 3100 & 675.5 & 11.11 & 320.64 & 72.96 & 1361.2 & 439 & 31 & 183 \\
\hline 5 & B.5 & 10470 & 2000 & 23.45 & 1282.5 & 364.8 & 5643.6 & 830 & 31 & 244 \\
\hline 6 & B.6 & 7000 & 1446 & 17.59 & 400.8 & 486.4 & 3658.4 & 765 & 31 & 183 \\
\hline 7 & R.1 & 3390 & 682 & 15.74 & 300.6 & 145.9 & 1503.1 & 452 & 31 & 244 \\
\hline 8 & R.2 & 2565 & 630 & 10 & 200.4 & 48.64 & 1047.5 & 289 & 31 & 305 \\
\hline 9 & Kh.1 & 2550 & 525.5 & 14.81 & 260.52 & 48.64 & 864.98 & 2286 & 31 & 4888 \\
\hline 10 & Kh.2 & 3600 & 980 & 21.29 & 200.4 & 48.64 & 1435.7 & 314 & 31 & 549 \\
\hline 11 & Kh.3 & 3390 & 761 & 12.96 & 220.44 & 133.7 & 1425.9 & 248 & 31 & 549 \\
\hline 12 & Kh.4 & 1960 & 412.5 & 7.77 & 180.36 & 48.64 & 716.09 & 164 & 31 & 366 \\
\hline 13 & Kh.5 & 3692 & 980 & 13.88 & 280.56 & 97.28 & 1651.9 & 480 & 31 & 152.5 \\
\hline 14 & Kh.6 & 1810 & 373.3 & 7.77 & 160.32 & 48.64 & 514.02 & 419 & 31 & 244 \\
\hline
\end{tabular}

Table (2): Results of chemical analysis of groundwater of the Cambro-

Ordovician Sandstones aquifer.

\begin{tabular}{|c|c|c|c|c|c|c|c|c|c|c|}
\hline Well & Code & \multirow{2}{*}{ NDS } & \multicolumn{4}{|c|}{ Cations } & \multicolumn{4}{|c|}{ Anions } \\
\cline { 4 - 11 } & & & NA $^{++}$ & K$^{+}$ & $\mathbf{C a}^{++}$ & Mg $^{++}$ & Cl$^{-}$ & SO4$^{--}$ & CO3 $^{--}$ & HCO3-- $^{--}$ \\
\hline $\mathbf{1 5}$ & S.S.4 & 1420 & 317.7 & 7.77 & 100.2 & 24.32 & 261.26 & 410 & 31 & 244 \\
\hline $\mathbf{1 6}$ & S.S.5 & 1060 & 200 & 5.55 & 80.16 & 36.48 & 223.33 & 202 & 31 & 244 \\
\hline $\mathbf{1 7}$ & S.S.6 & 680 & 110 & 5.55 & 60.12 & 24.32 & 90.04 & 208 & 31 & 122 \\
\hline $\mathbf{1 8}$ & S.S.7 & 825 & 200 & 12.96 & 40.08 & 12.16 & 133.64 & 202 & 31 & 183 \\
\hline $\mathbf{1 9}$ & S.S.8 & 1090 & 170 & 7.77 & 140.28 & 36.48 & 347.17 & 226 & 31 & 122 \\
\hline $\mathbf{2 0}$ & S.S.9 & 715 & 59.7 & 5.55 & 100.2 & 36.48 & 70.9 & 221 & 31 & 183 \\
\hline $\mathbf{2 1}$ & S.S.10 & 307 & 55 & 6.66 & 20.04 & 12.16 & 35.45 & 72.48 & 31 & 61 \\
\hline $\mathbf{2 2}$ & Ag.1 & 3995 & 840 & 18.51 & 360.72 & 145.92 & 1726.41 & 681 & 31 & 183 \\
\hline $\mathbf{2 3}$ & Ag.2 & 3120 & 440 & 15.74 & 681.36 & 194.56 & 1751.23 & 765 & 31 & 183 \\
\hline $\mathbf{2 4}$ & Ag.3 & 1100 & 330 & 5.55 & 20.04 & 12.16 & 237.51 & 235 & 31 & 183 \\
\hline $\mathbf{2 5}$ & Ag.4 & 1350 & 344 & 6.66 & 60.12 & 24.32 & 251.69 & 314 & 31 & 305 \\
\hline $\mathbf{2 6}$ & Ag.5 & 1100 & 317 & 7.77 & 20.04 & 12.16 & 173.7 & 278 & 31 & 244 \\
\hline $\mathbf{2 7}$ & Sh.1 & 650 & 140 & 5.55 & 40.08 & 12.16 & 74.44 & 144 & 31 & 183 \\
\hline $\mathbf{2 8}$ & Sh.2 & 715 & 120 & 6.66 & 60.12 & 24.32 & 106.35 & 111.84 & 31 & 244 \\
\hline $\mathbf{2 9}$ & At.1 & 780 & 220 & 3.88 & 20.04 & 12.16 & 198.52 & 139.7 & 31 & 122 \\
\hline $\mathbf{3 0}$ & Nb.1 & 820 & 187.5 & 5.55 & 60.12 & 12.16 & 152.43 & 238 & 31 & 122 \\
\hline
\end{tabular}


Table (3): Results of chemical analysis of groundwater of the fractured Precambrian basement aquifer.

\begin{tabular}{|c|c|c|c|c|c|c|c|c|c|c|}
\hline \multirow{2}{*}{$\begin{array}{l}\text { Well } \\
\text { No. }\end{array}$} & \multirow[t]{2}{*}{ Code } & \multirow[t]{2}{*}{ TDS } & \multicolumn{4}{|c|}{ Cations } & \multicolumn{4}{|c|}{ Anions } \\
\hline & & & $\mathbf{N A + +}$ & $\mathbf{K}+$ & $\mathrm{Ca}++$ & Mg++ & $\mathrm{Cl}-$ & SO4-- & CO3-- & HCO3-- \\
\hline 31 & S.1 & 1920 & 391 & 7.77 & 80.16 & 48.64 & 436.1 & 423 & 31 & 183 \\
\hline 32 & Z.1 & 5800 & 1481 & 13.88 & 400.8 & 145.9 & 7222.6 & 742 & 31 & 183 \\
\hline 33 & Bd.1 & 432 & 55 & 3.7 & 6.12 & 12.16 & 56.72 & 86.4 & 31 & 122 \\
\hline 34 & Sha.1 & 710 & 180 & 8.88 & 4.08 & 12.16 & 207.4 & 96 & 31 & 122 \\
\hline 35 & Sha.2 & 1990 & 630 & 16.66 & 40.08 & 24.32 & 786.9 & 260 & 31 & 183 \\
\hline 36 & S.S.1 & 1515 & 330 & 8.88 & 160.3 & 24.32 & 577.5 & 251 & 31 & 122 \\
\hline 37 & S.S.2 & 1190 & 220 & 5.55 & 160.3 & 12.16 & 379.3 & 236 & 31 & 122 \\
\hline 38 & S.S.3 & 980 & 120 & 3.88 & 140.3 & 36.48 & 269.4 & 127 & 31 & 224 \\
\hline
\end{tabular}

Table (4): Trace element distributions of groundwater of the quaternary alluvial aquifer.

\begin{tabular}{|c|c|c|c|c|c|c|c|c|c|}
\hline $\begin{array}{c}\text { Well } \\
\text { No. }\end{array}$ & Code & Cd & Co & Cr & Fe & Mn & As & Pb & Cu \\
\hline $\mathbf{1}$ & B1 & 9.56 & 9.05 & 17.07 & 287.6 & 44.9 & 48.64 & 23.13 & n.d \\
\hline $\mathbf{2}$ & B2 & 10.75 & 17.6 & 17.9 & 422.3 & 406.8 & 212.7 & 15.76 & 1.29 \\
\hline $\mathbf{3}$ & B3 & 11.92 & 16.56 & 16.76 & 65.3 & 13.3 & 122.2 & 14.49 & n.d \\
\hline $\mathbf{4}$ & B4 & 14.1 & 13.3 & 22.3 & n.d & 141.6 & 301.1 & 21.3 & n.d \\
\hline $\mathbf{5}$ & B5 & 12.2 & 6.91 & 26 & 247.6 & 196.1 & 143.7 & 26.85 & 13.1 \\
\hline $\mathbf{6}$ & B6 & 11.7 & 16.5 & 18.8 & n.d & n.d & 282.7 & 22.71 & 1.92 \\
\hline $\mathbf{7}$ & R1 & 19.8 & 22.6 & 21.1 & 247.6 & 196.1 & 139.2 & 18.1 & 4.46 \\
\hline $\mathbf{8}$ & R2 & 10.3 & 9.1 & 18.8 & 427.5 & n.d & n.d & 18.1 & 16.3 \\
\hline $\mathbf{9}$ & Kh1 & 14.5 & 6.7 & 24.7 & 99.5 & 1.7 & 128.2 & 17.3 & 87.5 \\
\hline $\mathbf{1 0}$ & Kh2 & 11.8 & 3.92 & 21.9 & 516.7 & 34.1 & 132.4 & 29.4 & 98.9 \\
\hline $\mathbf{1 1}$ & Kh3 & 16.3 & 8.2 & 18.1 & 422.3 & 81 & 108.1 & 27.2 & 91.1 \\
\hline $\mathbf{1 2}$ & Kh4 & 19.7 & 10.5 & 22.2 & 205 & 56.7 & 16.9 & 10.6 & 18.3 \\
\hline $\mathbf{1 3}$ & Kh5 & 21.2 & 9.08 & 22.8 & 81.6 & 3.7 & 138.4 & 28.2 & 99.2 \\
\hline $\mathbf{1 4}$ & Kh6 & 17.8 & 11.01 & 25.7 & 939.6 & 91 & 121.1 & 24.8 & 78.1 \\
\hline
\end{tabular}


Table (5): Trace element distributions of groundwater of the CambroOrdovician sandstone aquifer.

\begin{tabular}{|c|c|c|c|c|c|c|c|c|c|}
\hline $\begin{array}{c}\text { Well } \\
\text { No. }\end{array}$ & Code & Cd & Co & Cr & As & Fe & Mn & Pb & Cu \\
\hline $\mathbf{1 5}$ & SS4 & 183.4 & 26.08 & 28.4 & 214.76 & 355.4 & 3.8 & 27.97 & 38.74 \\
\hline $\mathbf{1 6}$ & SS5 & 612.46 & 19.91 & 44.69 & 126.75 & 117.5 & n.d & 19.06 & 73.28 \\
\hline $\mathbf{1 7}$ & SS6 & 41.21 & 18.9 & 39.15 & 159.87 & 258 & 2.7 & 23.45 & 17.82 \\
\hline $\mathbf{1 8}$ & SS7 & 27.05 & 26.72 & 29.46 & 241.08 & n.d & n.d & 33.71 & 4.09 \\
\hline $\mathbf{1 9}$ & SS8 & 10.62 & 4.46 & 24.26 & 183.35 & 58.5 & n.d & 30.99 & 63 \\
\hline $\mathbf{2 0}$ & SS9 & 34.87 & 18.45 & 24.97 & 176.38 & 1271.6 & n.d & 29.81 & 51.74 \\
\hline $\mathbf{2 1}$ & SS10 & 14.7 & 27.63 & 16.86 & 158.4 & 314.4 & 25 & 26.7 & 48.9 \\
\hline $\mathbf{2 2}$ & Ag1 & 11.98 & 21.39 & 19.56 & 198.06 & n.d & 35 & 12.8 & n.d \\
\hline $\mathbf{2 3}$ & Ag2 & 13.35 & 15.47 & 30.41 & 27.14 & 96.2 & 41.6 & n.d & 2.35 \\
\hline $\mathbf{2 4}$ & Ag3 & 11.8 & 7.52 & 38.03 & 232.02 & 4.95 & n.d & 4.85 & 26.87 \\
\hline $\mathbf{2 5}$ & Ag4 & 11.31 & 11.12 & 20.87 & 242.2 & 82.2 & 44.9 & n.d & n.d \\
\hline $\mathbf{2 6}$ & Ag5 & 12.8 & 18.7 & 37.8 & 232.8 & 176.7 & 40.6 & 7.85 & 32.08 \\
\hline $\mathbf{2 7}$ & Nb1 & 34.99 & 18.25 & 27.88 & 85.99 & 63.1 & n.d & 23.89 & 10.44 \\
\hline $\mathbf{2 8}$ & At1 & 72.53 & 2.62 & 16.11 & 113.2 & 54.5 & 19.1 & n.d & n.d \\
\hline $\mathbf{2 9}$ & Sh1 & 10.8 & 8.6 & 13.2 & 195.8 & 98.6 & 2.8 & n.d & n.d \\
\hline $\mathbf{3 0}$ & Sh2 & 187.3 & 16.33 & 38.96 & 18.08 & 59.6 & 14.6 & 34.89 & 33.44 \\
\hline
\end{tabular}

Table (6): Trace element distributions of groundwater of the fractured Precambrian basement aquifer.

\begin{tabular}{|c|c|c|c|c|c|c|c|c|c|}
\hline $\begin{array}{c}\text { Well } \\
\text { No. }\end{array}$ & Code & Cd & Co & Cr & Fe & Mn & As & Pb & Cu \\
\hline $\mathbf{3 1}$ & Z1 & 10.2 & 4.05 & 18.7 & 111.17 & 12 & 77.3 & 12.1 & 101.1 \\
\hline $\mathbf{3 2}$ & S1 & 11 & 2 & 21.4 & 113.4 & 0.51 & 81.5 & 13.2 & 107.8 \\
\hline $\mathbf{3 3}$ & Bd1 & 9.08 & 14.1 & 31.2 & 106.7 & 2 & 143.2 & 24.1 & 36 \\
\hline $\mathbf{3 4}$ & Sha1 & 13.8 & 11.2 & 19.7 & 20.2 & n.d & 242.2 & 3.49 & n.d \\
\hline $\mathbf{3 5}$ & Sha2 & 12.2 & 4.92 & 15.3 & 36.9 & n.d & 113.2 & 18.9 & n.d \\
\hline $\mathbf{3 6}$ & SS1 & 12.87 & 12.28 & 16.55 & 400.8 & 21.1 & 111.73 & 6.28 & n.d \\
\hline $\mathbf{3 7}$ & SS2 & 10.9 & 16.98 & 21.05 & 226.1 & n.d & 153.1 & 19.08 & 64.04 \\
\hline $\mathbf{3 8}$ & SS3 & 18.26 & 13.83 & 17.27 & 143.9 & n.d & 97.32 & 32.8 & n.d \\
\hline
\end{tabular}


Table (7): Radiometric distributions of the quaternary alluvial aquifer of the study area.

\begin{tabular}{|c|c|c|c|c|c|}
\hline Well No. & \multirow{2}{*}{ Code } & \multirow{2}{*}{ U ppb } & \multirow{2}{*}{ Th ppb } & \multicolumn{2}{|c|}{ Ra } \\
\cline { 5 - 6 } & & & Bq & Pci \\
\hline $\mathbf{1}$ & B1 & 679.4 & n.d & 0.02 & 0.56 \\
\hline $\mathbf{2}$ & B2 & 853.7 & 2.10 & n.d & n.d \\
\hline $\mathbf{3}$ & B3 & 1447.9 & n.d & n.d & n.d \\
\hline $\mathbf{4}$ & B 4 & 1450.1 & n.d & n.d & n.d \\
\hline $\mathbf{5}$ & B5 & 3335.5 & 1.68 & 0.11 & 3.04 \\
\hline $\mathbf{6}$ & B6 & 936.8 & n.d & n.d & n.d \\
\hline $\mathbf{7}$ & R1 & 1362.3 & n.d & n.d & n.d \\
\hline $\mathbf{8}$ & R2 & 1285.3 & n.d & n.d & n.d \\
\hline $\mathbf{9}$ & Kh1 & 1231.4 & n.d & 0.11 & 2.94 \\
\hline $\mathbf{1 0}$ & Kh2 & 1827.7 & n.d & 0.10 & 2.57 \\
\hline $\mathbf{1 1}$ & Kh3 & 1115.81 & 2.23 & n.d & n.d \\
\hline $\mathbf{1 2}$ & Kh4 & 928.64 & n.d & n.d & n.d \\
\hline $\mathbf{1 3}$ & Kh5 & 927.15 & n.d & 0.12 & 3.73 \\
\hline $\mathbf{1 4}$ & Kh6 & 728.1 & n.d & 0.02 & 0.47 \\
\hline
\end{tabular}

Table (8): Radiometric distributions of the fractured Precambrian basement aquifer of the study area.

\begin{tabular}{|c|c|c|c|c|c|}
\hline Well No. & \multirow{2}{*}{ Code } & \multirow{2}{*}{ U ppb } & \multirow{2}{*}{ Th ppb } & \multicolumn{2}{|c|}{ Ra } \\
\cline { 5 - 6 } & & & Bq & Pci \\
\hline $\mathbf{1 5}$ & SS4 & 824.8 & n.d & n.d & n.d \\
\hline $\mathbf{1 6}$ & SS5 & 517.94 & n.d & 0.01 & 0.26 \\
\hline $\mathbf{1 7}$ & SS6 & 472.1 & n.d & n.d & n.d \\
\hline $\mathbf{1 8}$ & SS7 & 621.57 & n.d & 0.04 & 1.02 \\
\hline $\mathbf{1 9}$ & SS 8 & 695.59 & 1.98 & n.d & n.d \\
\hline $\mathbf{2 0}$ & SS9 & 784.2 & n.d & n.d & n.d \\
\hline $\mathbf{2 1}$ & SS10 & 649.21 & n.d & n.d & n.d \\
\hline $\mathbf{2 2}$ & Ag1 & 1852.1 & 1.78 & n.d & n.d \\
\hline $\mathbf{2 3}$ & Ag2 & 705.9 & n.d & 0.05 & 1.32 \\
\hline $\mathbf{2 4}$ & Ag3 & 677.78 & 2.88 & 0.12 & 3.26 \\
\hline $\mathbf{2 5}$ & Ag4 & 1683.6 & n.d & 0.06 & 1.52 \\
\hline $\mathbf{2 6}$ & Ag5 & 1228.6 & 1.69 & n.d & n.d \\
\hline $\mathbf{2 7}$ & Nb1 & 1683.6 & n.d & 0.01 & 0.38 \\
\hline $\mathbf{2 8}$ & At1 & 787.7 & 2.01 & 0.13 & 3.58 \\
\hline $\mathbf{2 9}$ & Sh1 & 1195.6 & 1.67 & 0.01 & 0.33 \\
\hline $\mathbf{3 0}$ & Sh2 & 955.8 & n.d & n.d & n.d \\
\hline
\end{tabular}


Table (9): Radiometric distributions of the Cambro - Ordovician sandstone aquifers in the study area.

\begin{tabular}{|c|c|c|c|c|c|}
\hline Well. No. & \multirow{2}{*}{ Code } & \multirow{2}{*}{ U ppb } & \multirow{2}{*}{ Th ppb } & \multicolumn{2}{|c|}{ Ra } \\
\cline { 5 - 6 } & & & Bq & Pci \\
\hline $\mathbf{3 1}$ & Z1 & 1601.3 & n.d & 0.01 & 0.33 \\
\hline $\mathbf{3 2}$ & S1 & 1560.8 & n.d & 0.06 & 1.57 \\
\hline $\mathbf{3 3}$ & Bd1 & 385.6 & n.d & n.d & n.d \\
\hline $\mathbf{3 4}$ & Sha1 & 513.6 & n.d & 0.01 & 0.33 \\
\hline $\mathbf{3 5}$ & Sha & 1823.6 & n.d & n.d & n.d \\
\hline $\mathbf{3 6}$ & SS1 & 532.6 & n.d & 0.05 & 1.32 \\
\hline $\mathbf{3 7}$ & SS2 & 485.2 & n.d & 0.05 & 1.45 \\
\hline $\mathbf{3 8}$ & SS3 & 431.12 & n.d & 0.06 & 1.50 \\
\hline
\end{tabular}

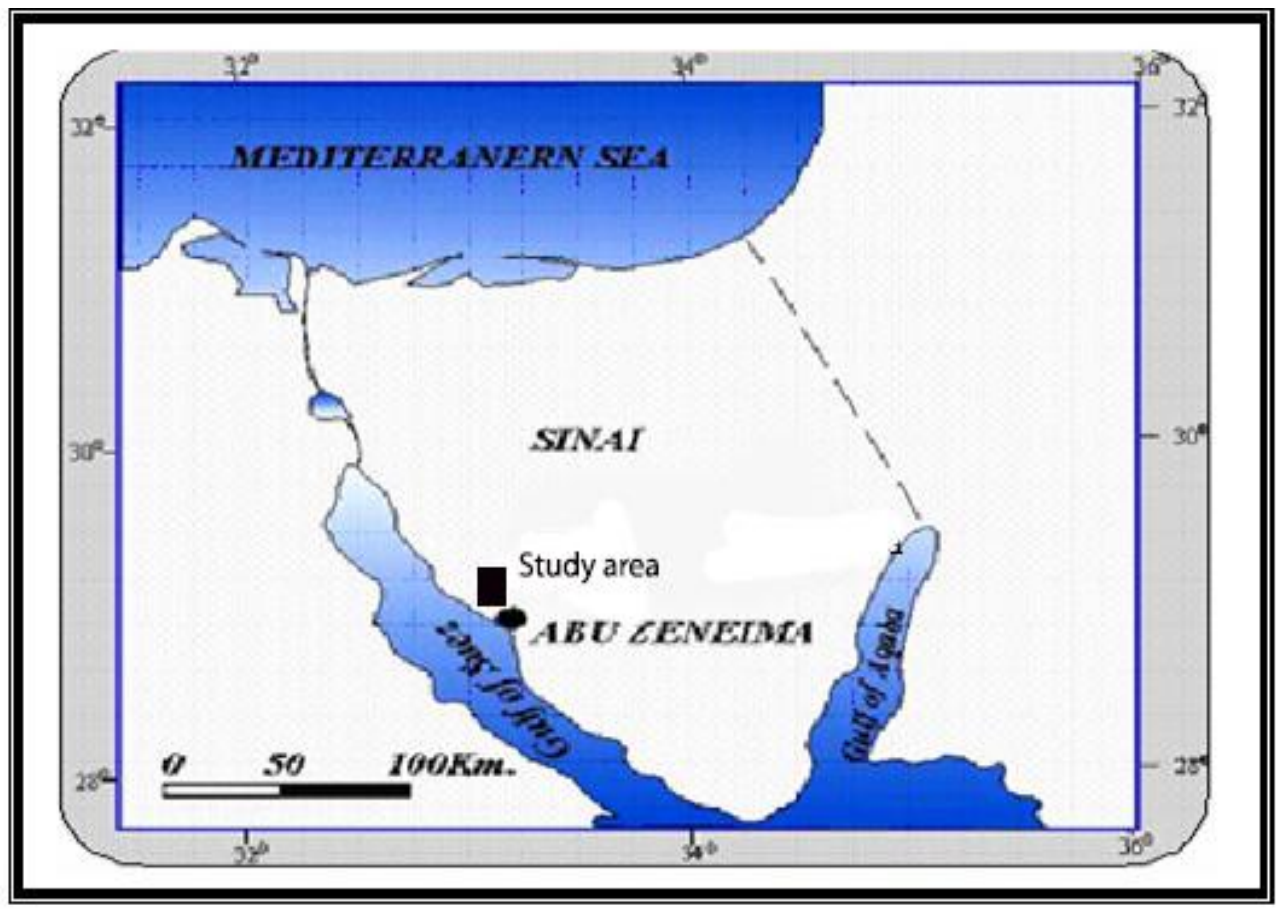

Fig. (1): Location map of the study area. 


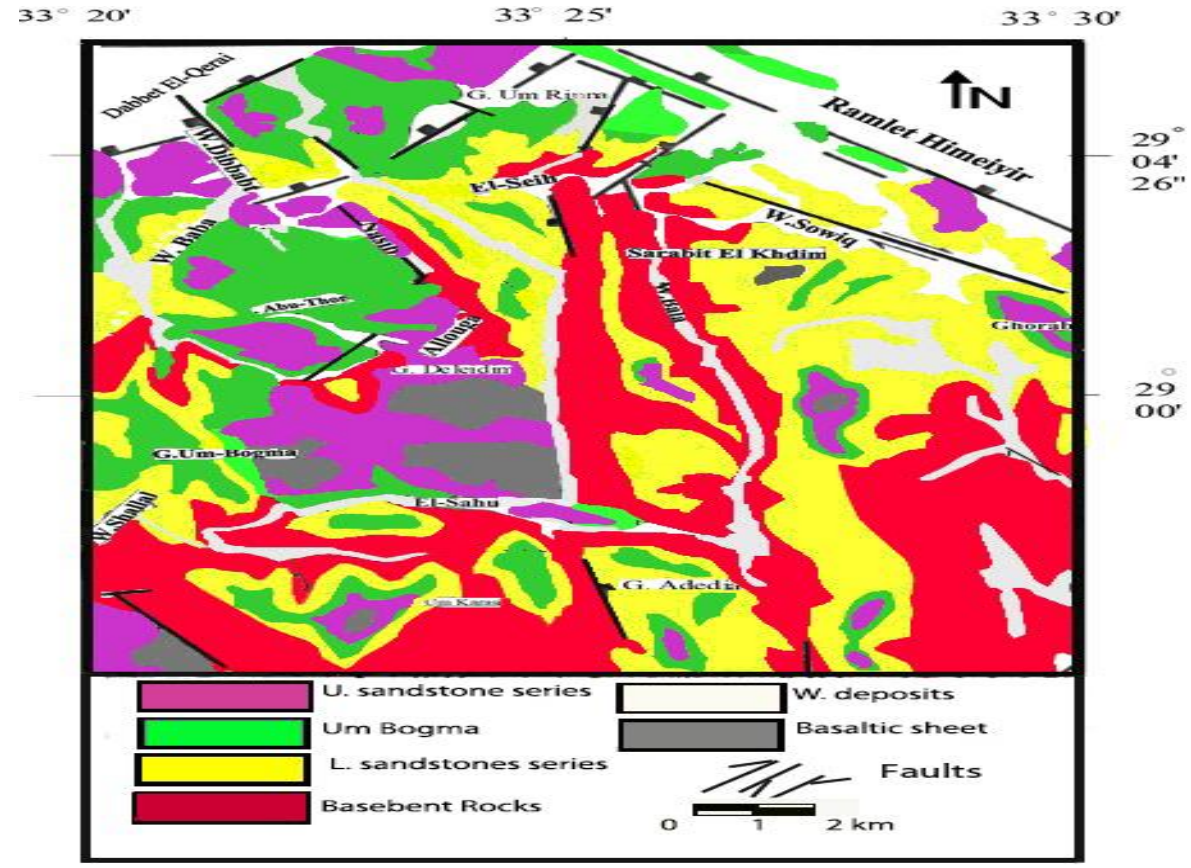

Fig. (2): Geological map of the studied area (modified after, Aita, 1996).

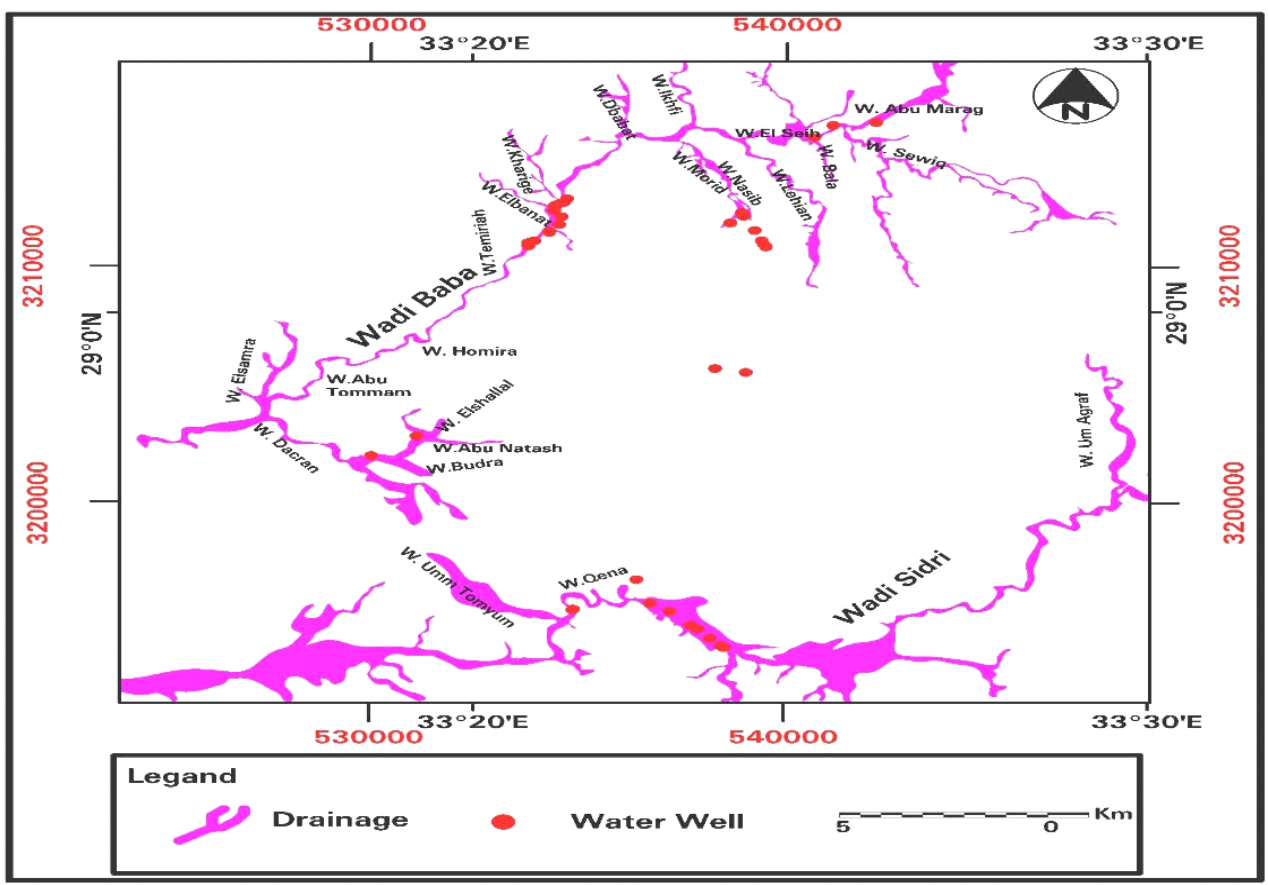

Fig. (3): Location map of the studied groundwater. 


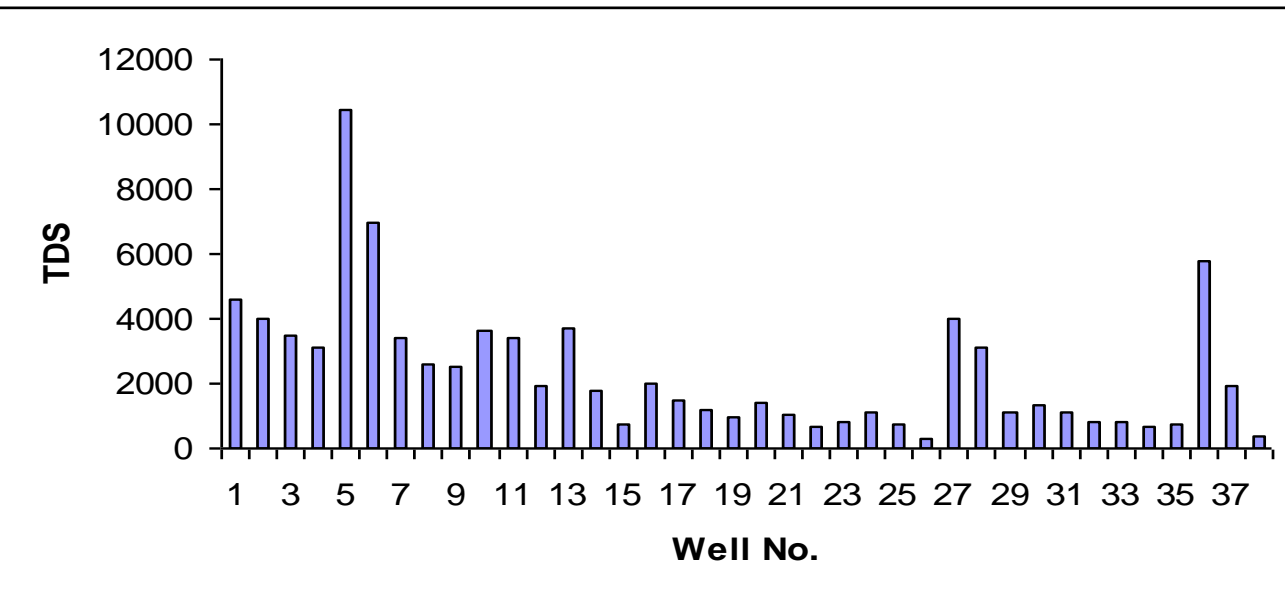

Fig. (4): Distribution of total salinity in groundwater of the study area.

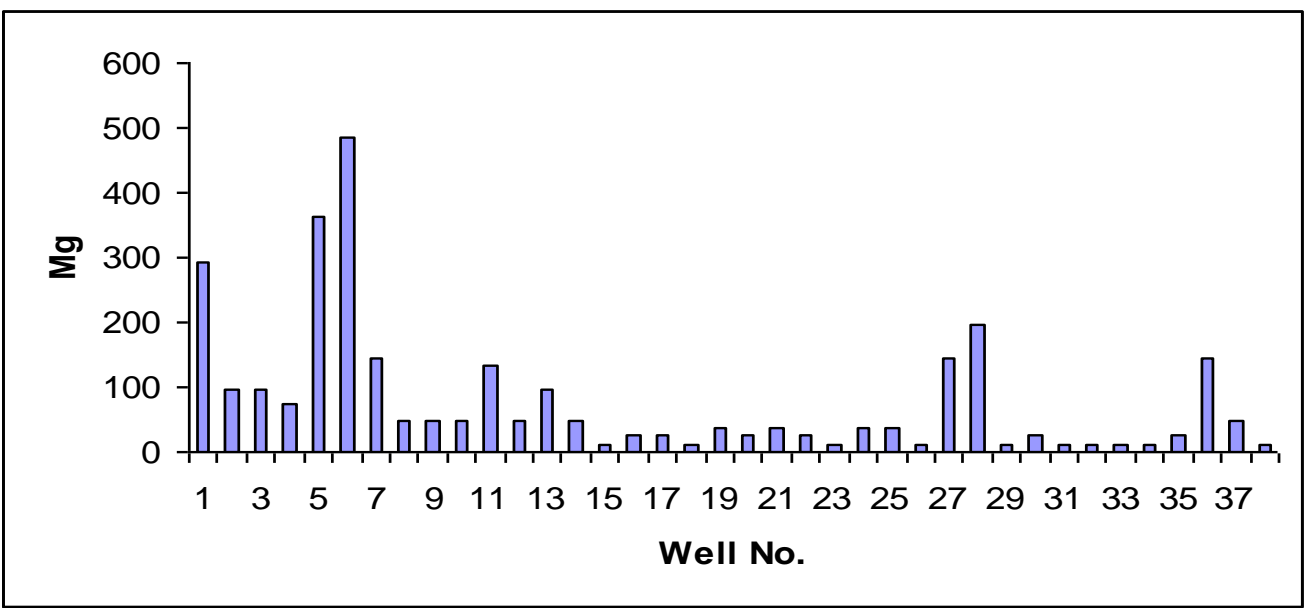

Fig. (5): Distribution of magnesium in groundwater of the study area.

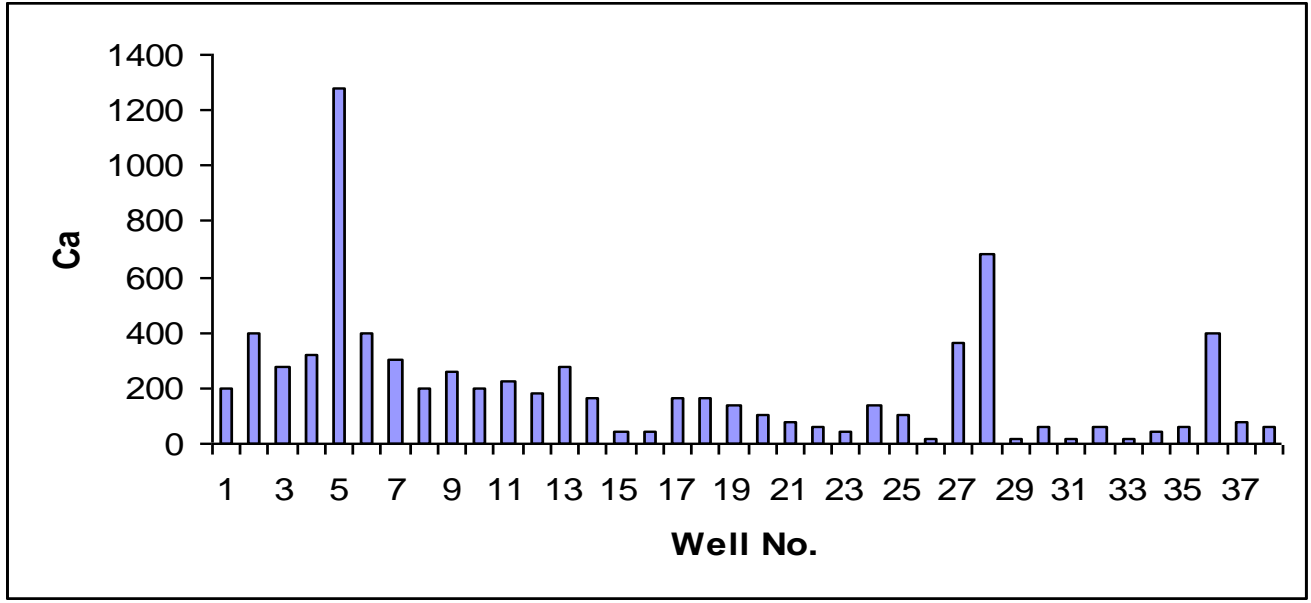

Fig. (6): Distribution of calcium in groundwater of the study area. 


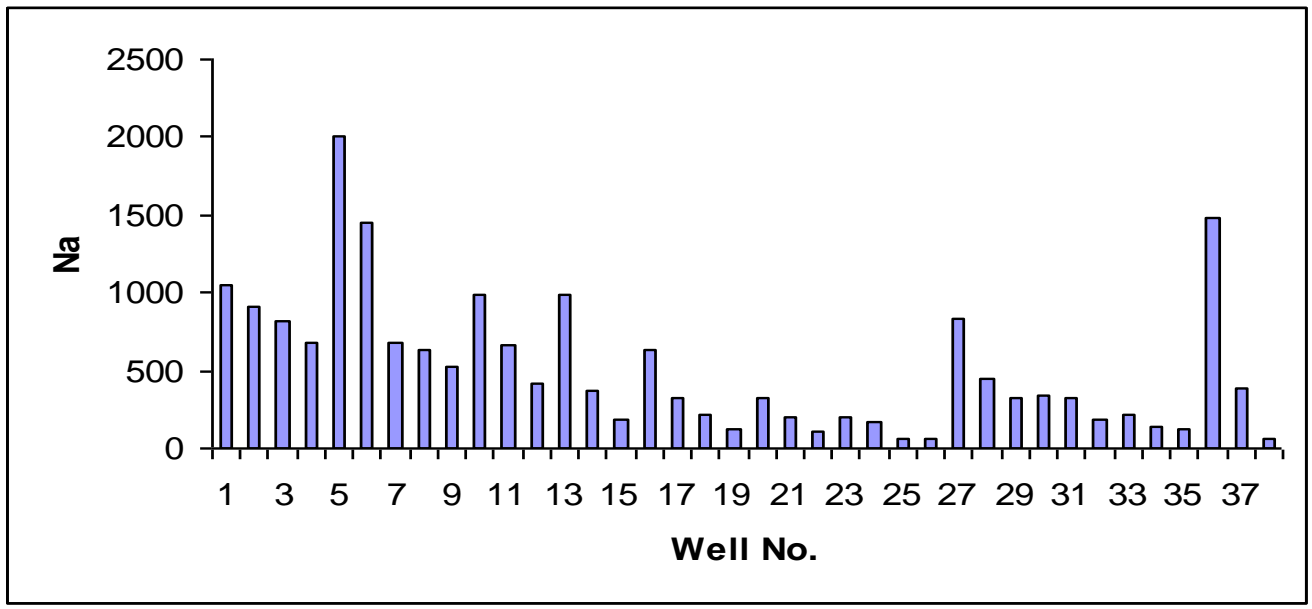

Fig. (7): Distribution of Sodium in groundwater of the study area

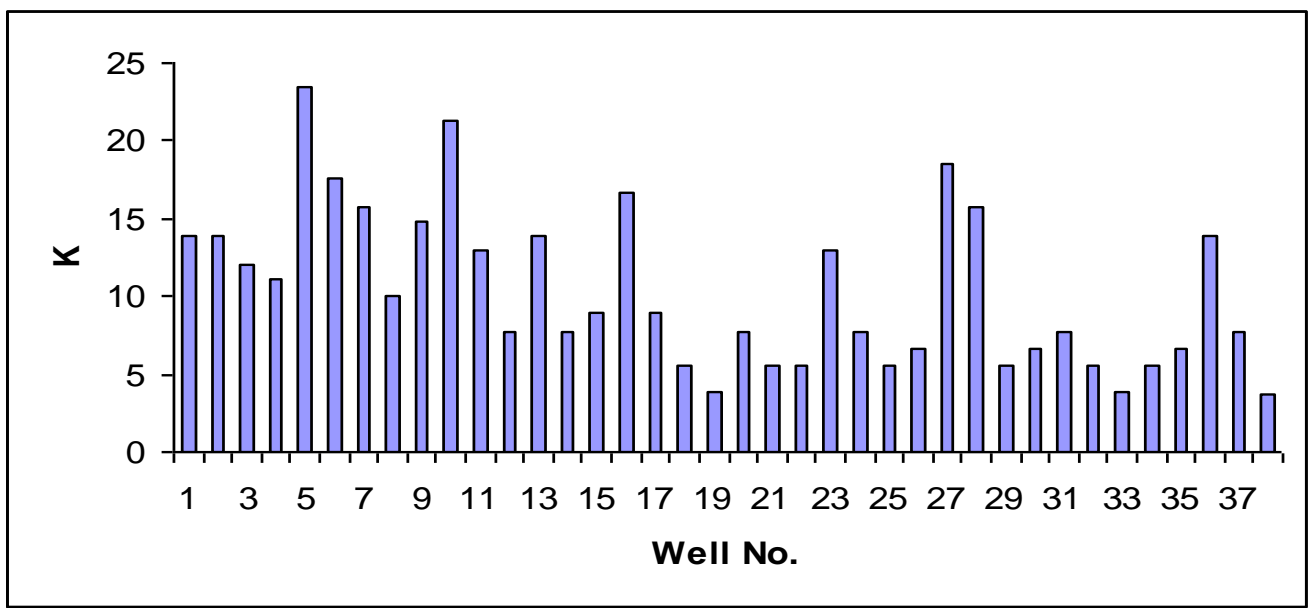

Fig. (8): Distribution of potassium in groundwater of the study area.

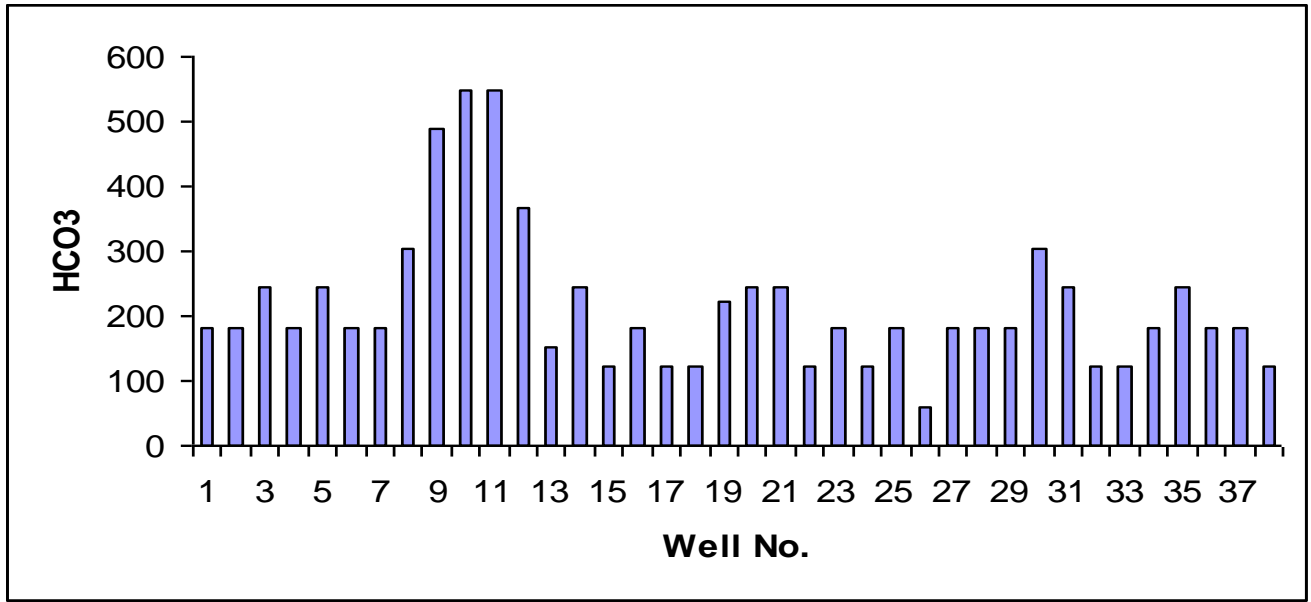

Fig. (9): Distribution of bicarbonate in groundwater of the study area. 


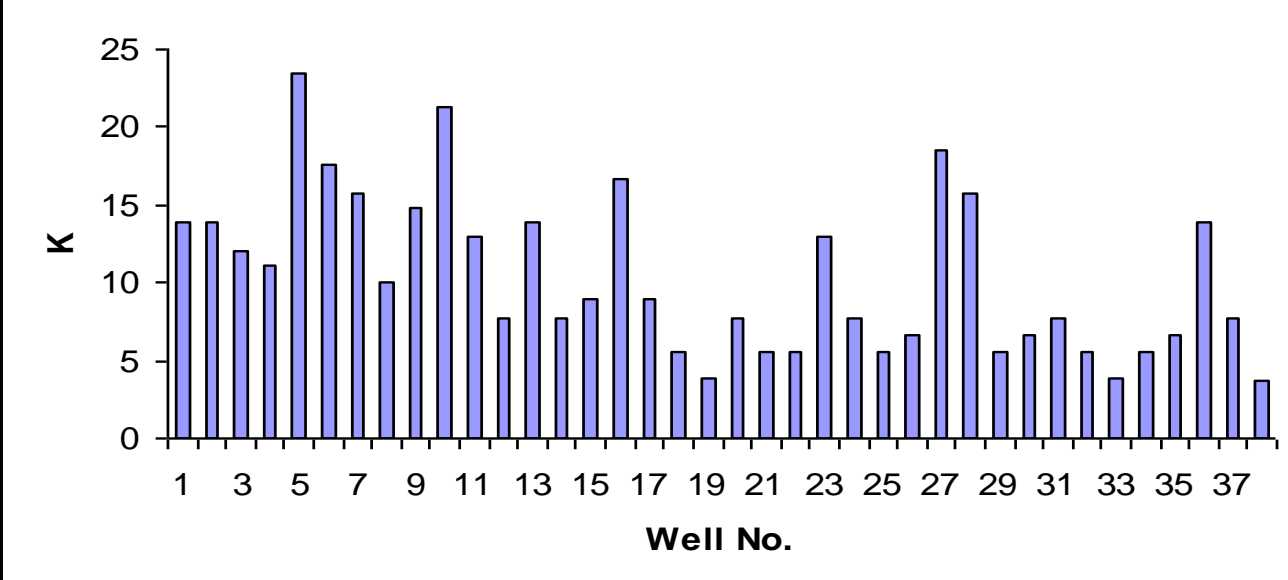

Fig. (10): Distribution of chloride in groundwater of the study area

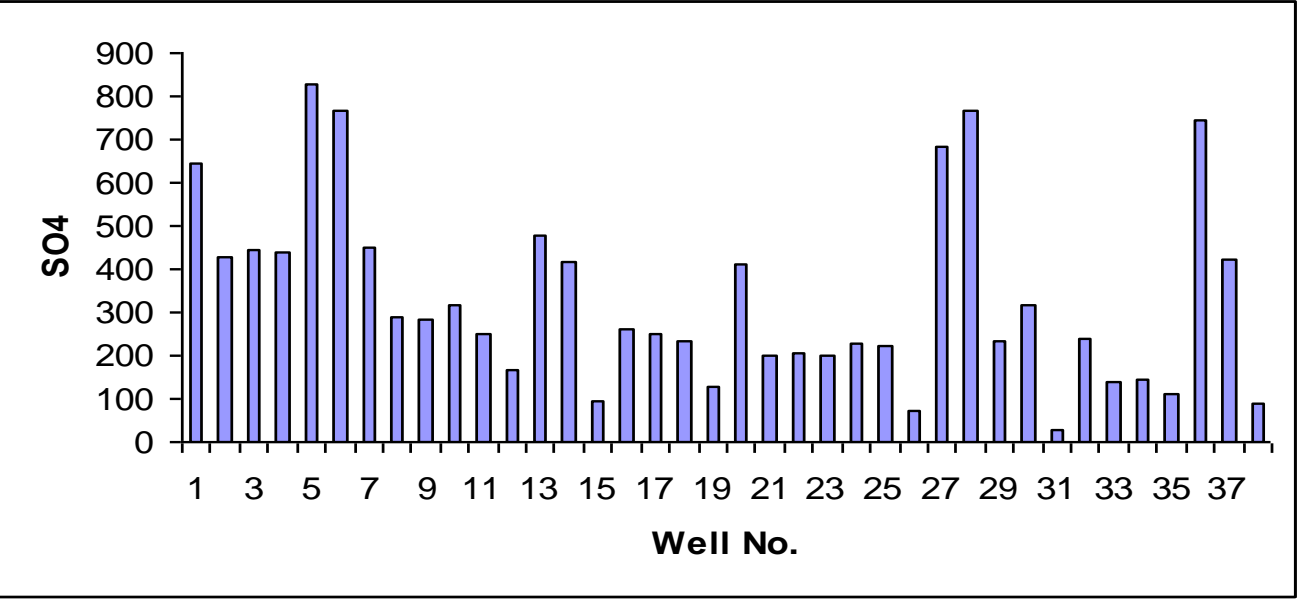

Fig. (11): Distribution of Sulphates in groundwater of the study area 


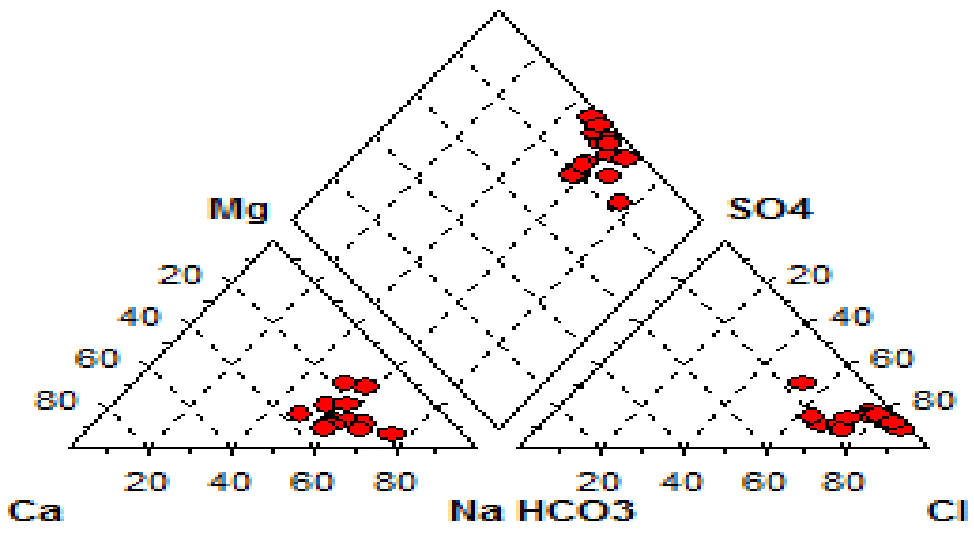

Fig. (12): Geochemical classification (Pipers diagram) of the Quaternary Alluvial aquifer

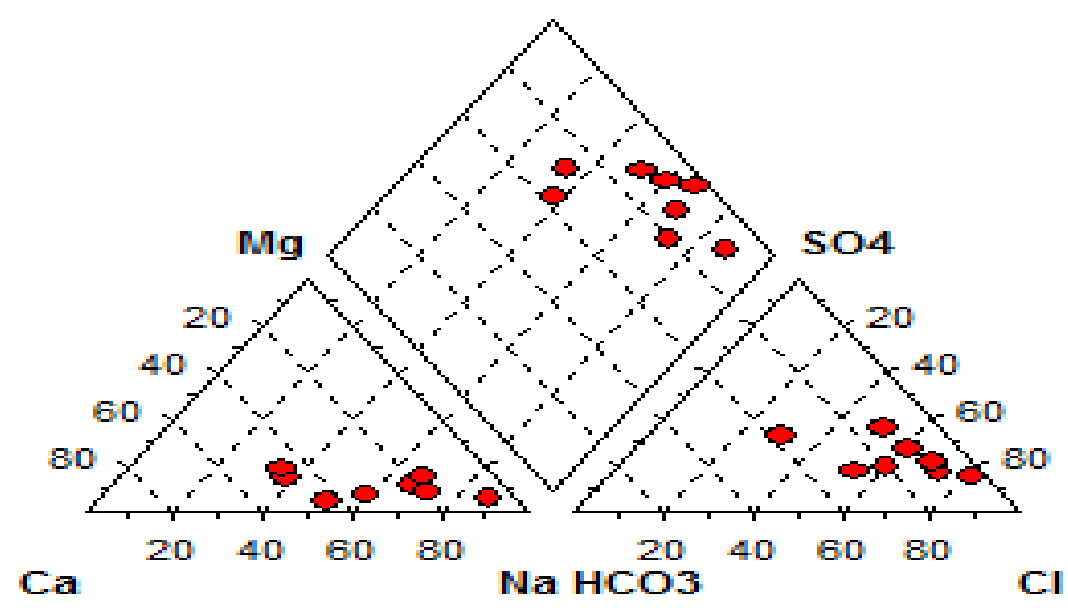

Fig. (13): Geochemical classification (Pipers diagram) of the CambroOrdovician aquifer

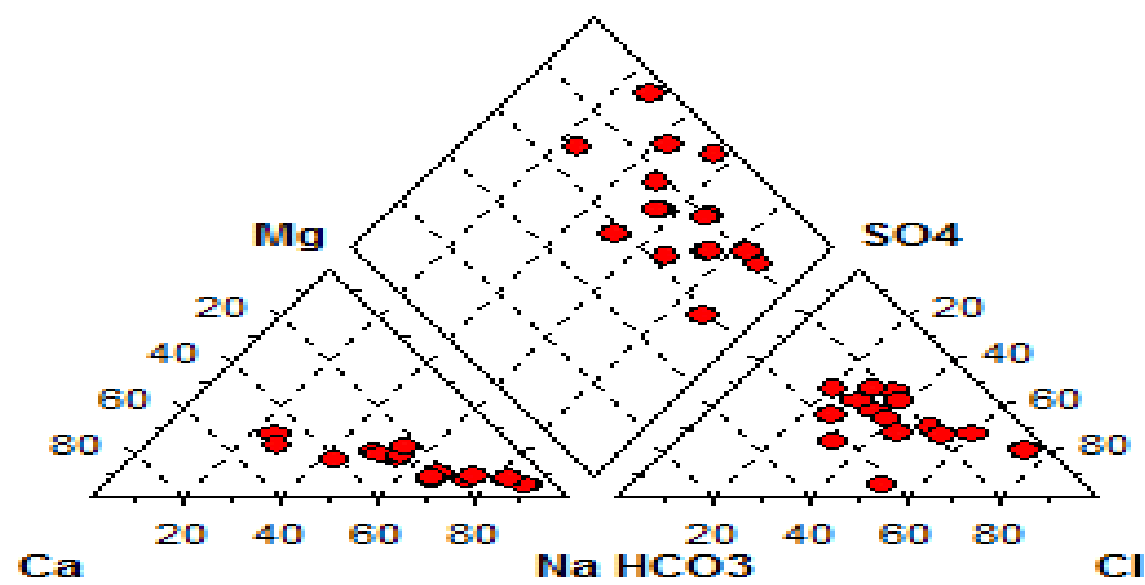

Fig. (14): Geochemical classification (Pipers diagram) of the Precambrian Fractured basement aquifer 


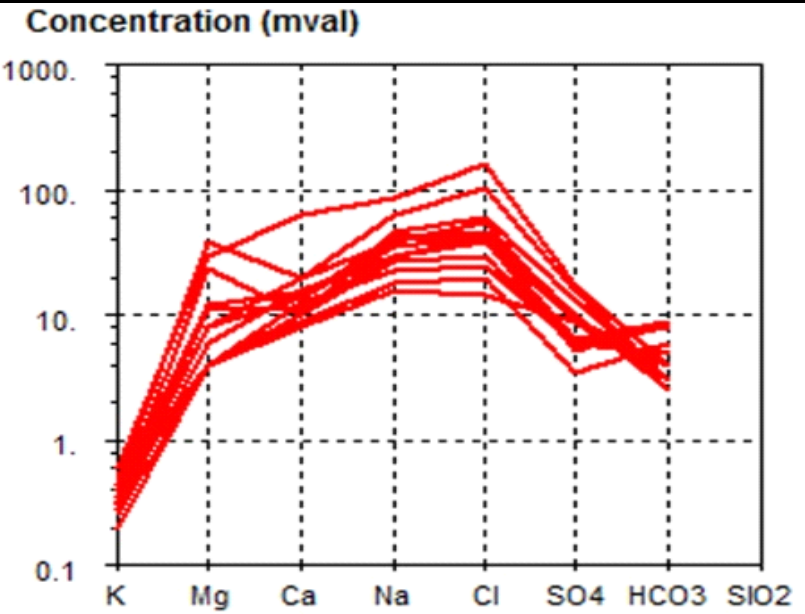

Fig. (15): Geochemical classification (Schoellers diagram) of the Quaternary Alluvial aquifer in the study area

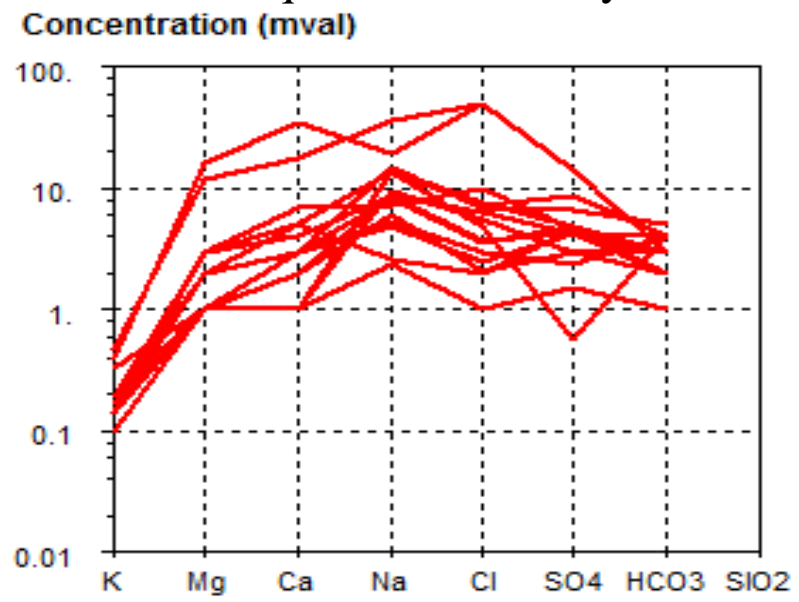

Fig. (16): Geochemical classification (Schoellers diagram) of the CambroOrdovician aquifer in the study area

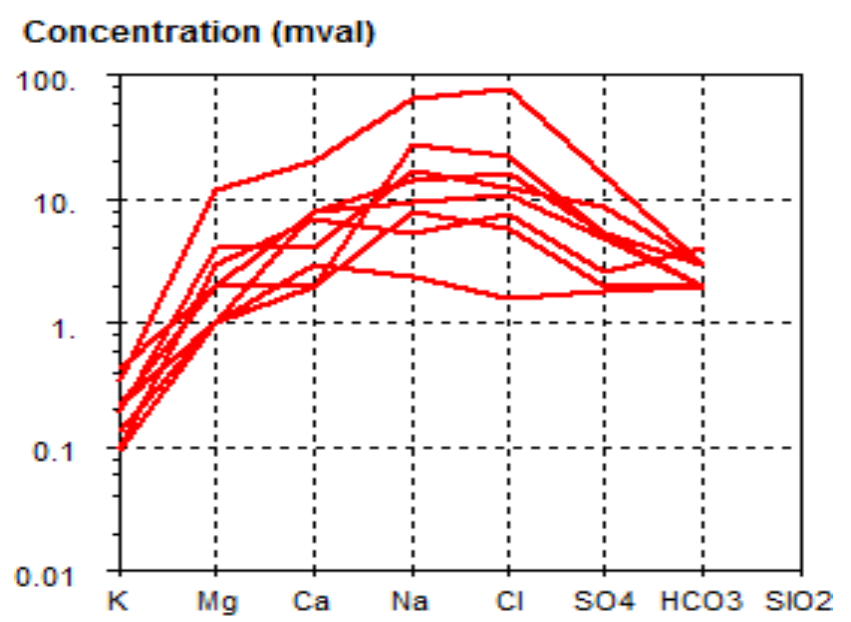

Fig. (17): Geochemical classification (Schoellers diagram) of the Precambrian Fractured basement aquifer in the study area 


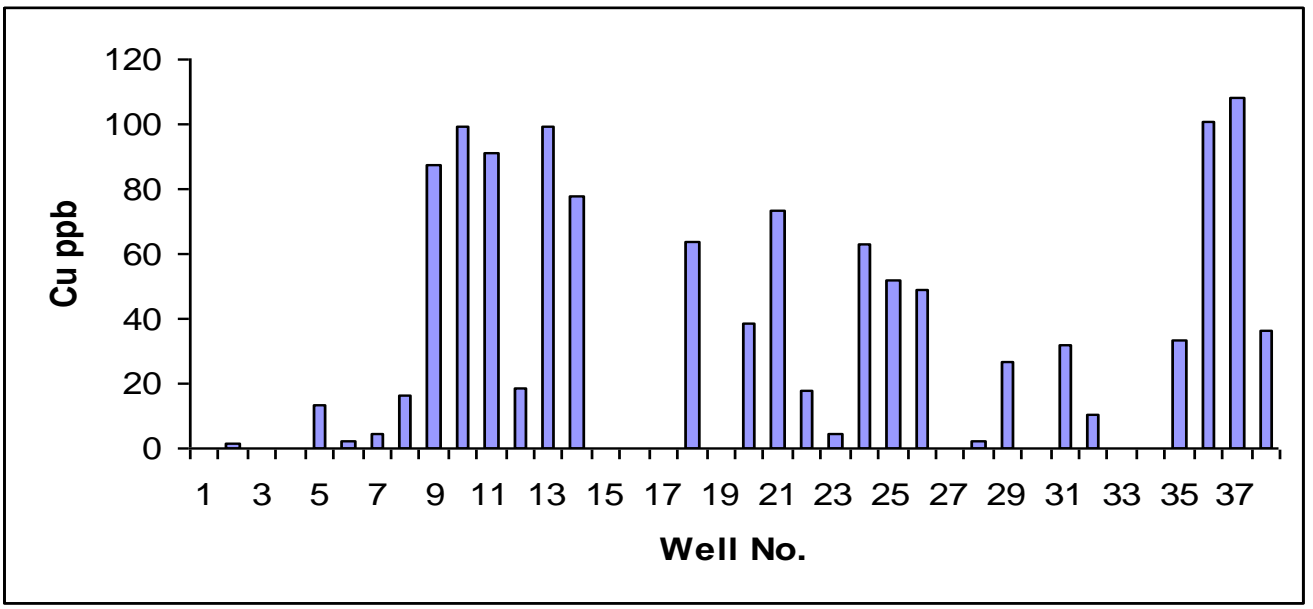

Fig. (18): Distribution of copper in groundwater of the study area

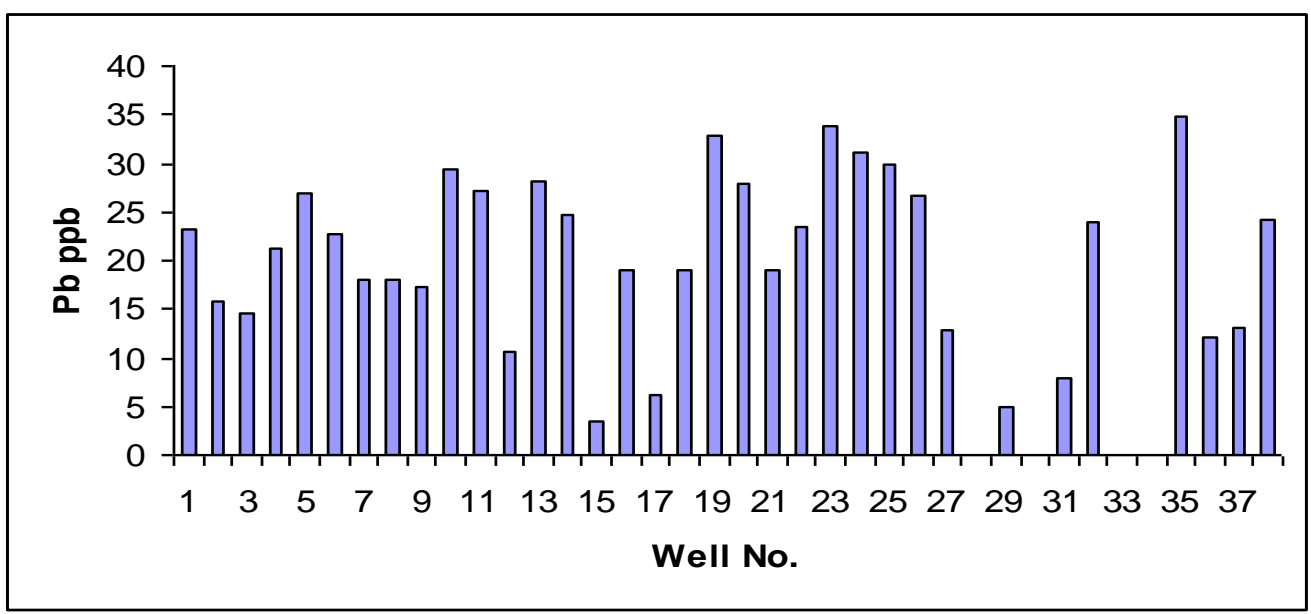

Fig. (19): Distribution of lead in groundwater of the study area

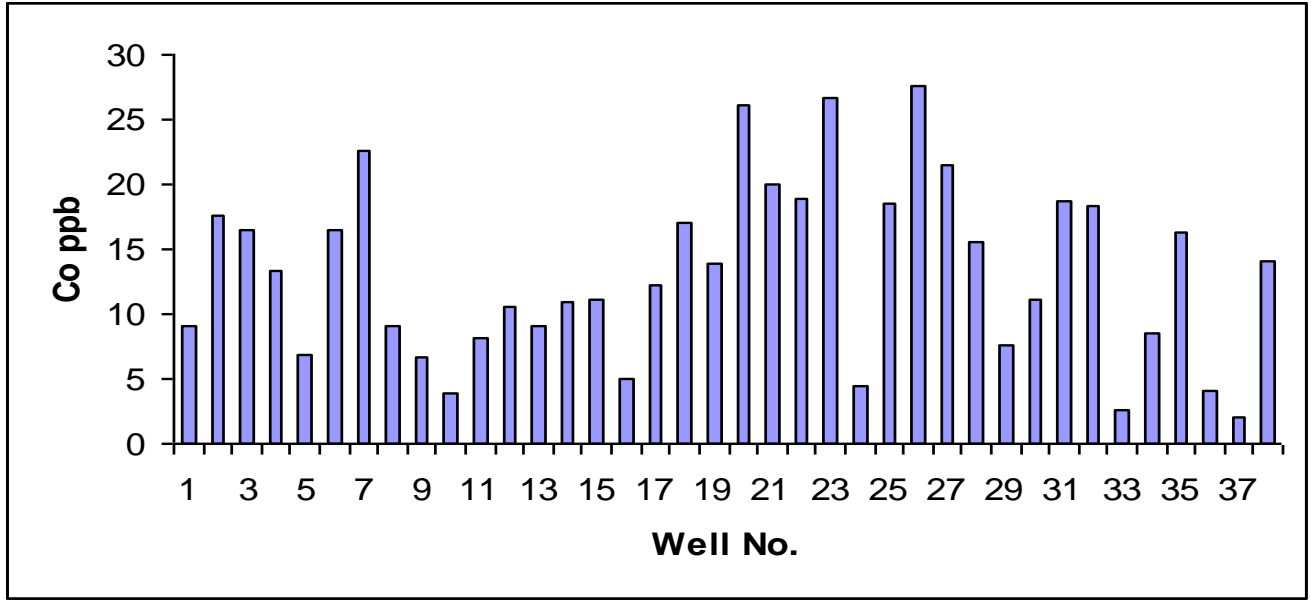

Fig. (20): Distribution of Cadmium in groundwater of the study area 


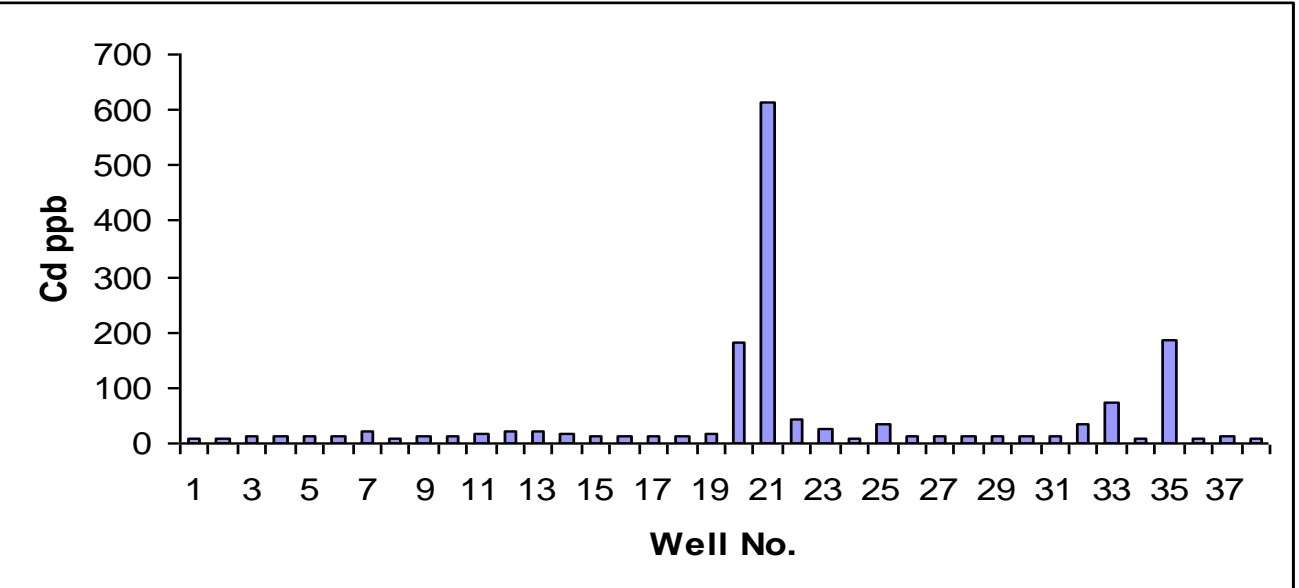

Fig. (21): Distribution of Cobalt in groundwater of the study area

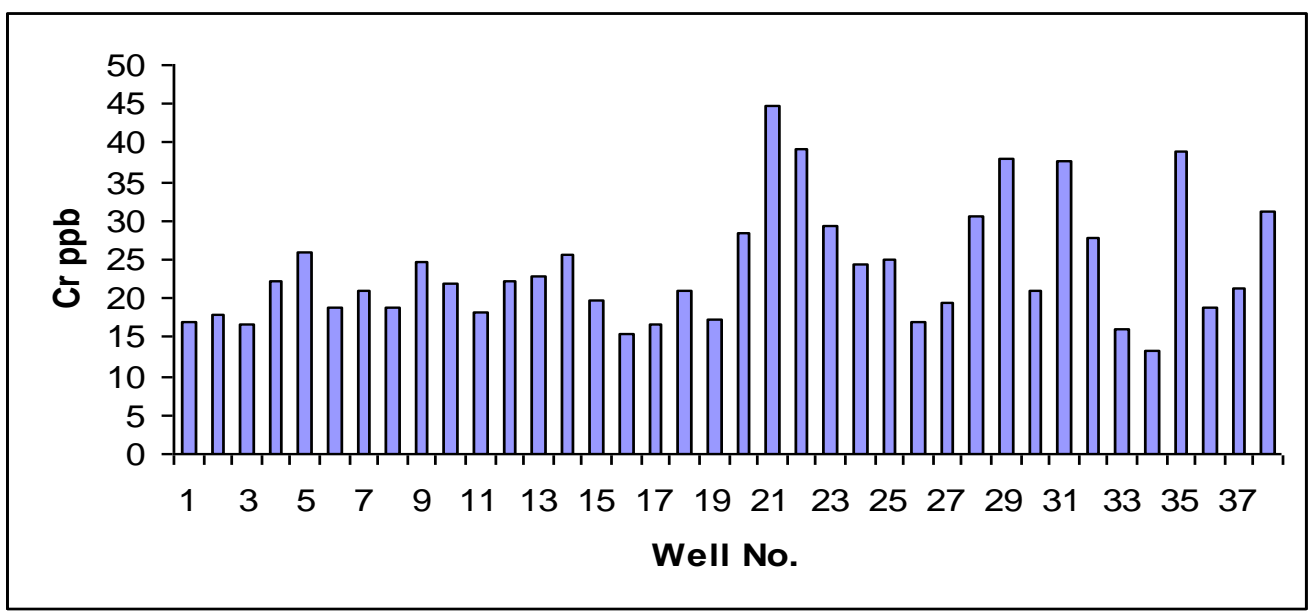

Fig. (22): Distribution of Chromium in groundwater of the study area

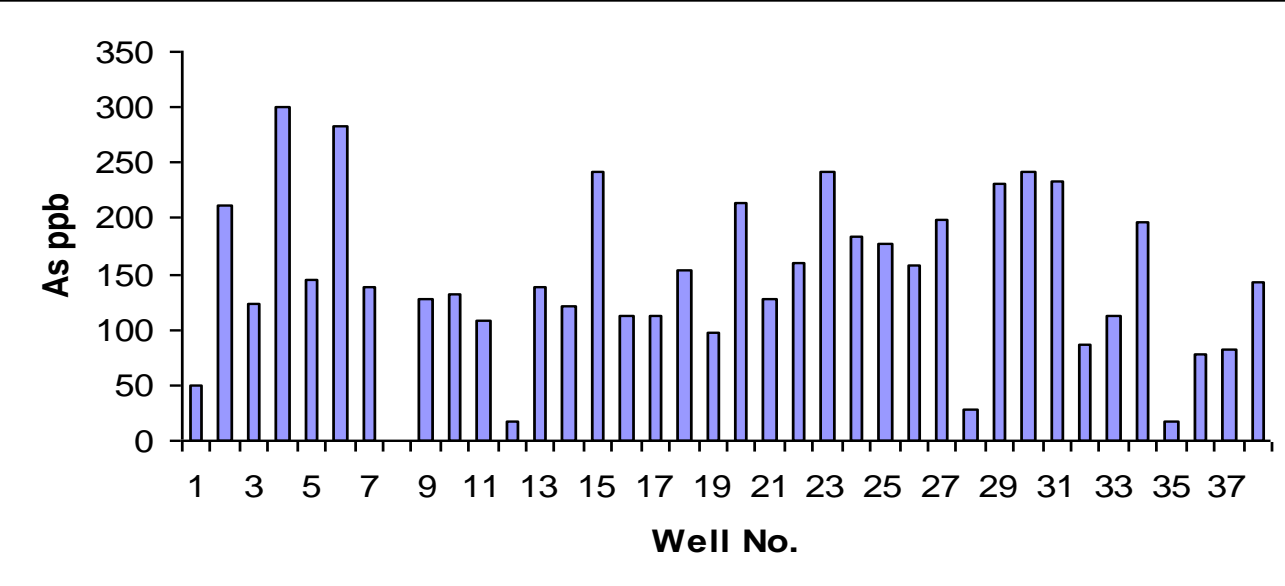

Fig. (23): Distribution of Arsinic in groundwater of the study area 


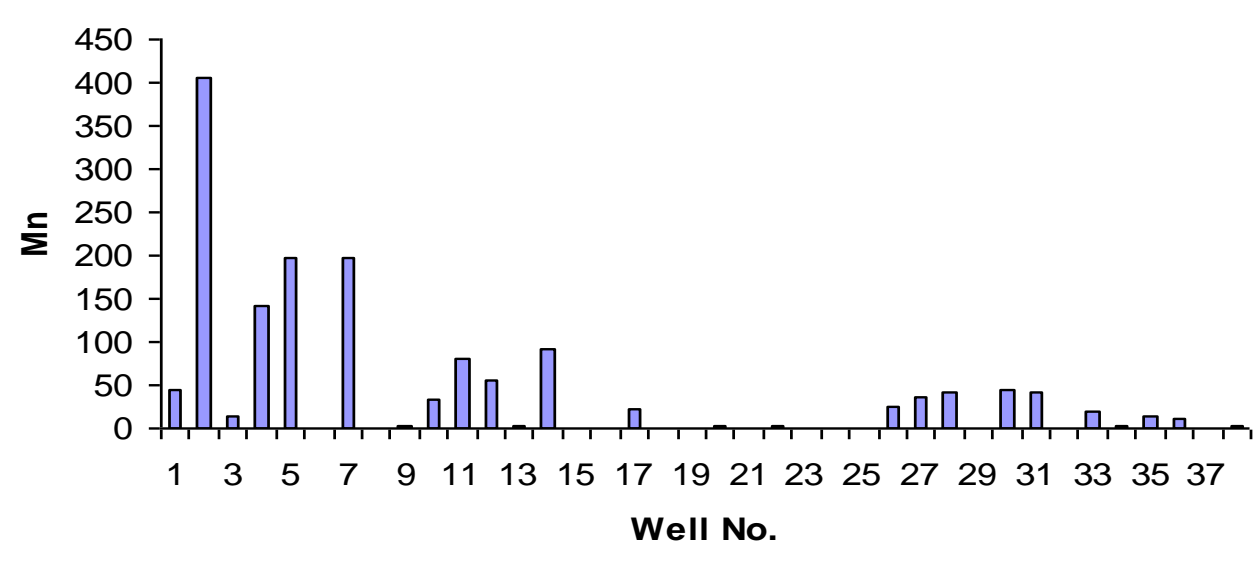

Fig. (24): Distribution of Manganese in groundwater of the study area

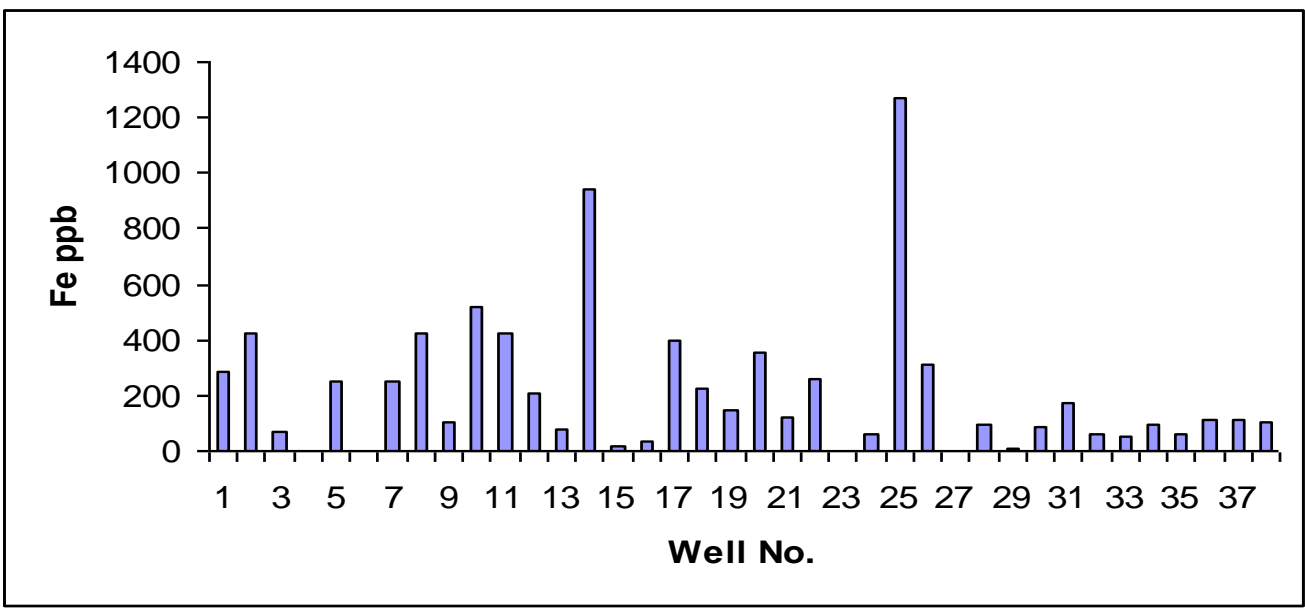

Fig. (25): Distribution of Iron in groundwater of the study area

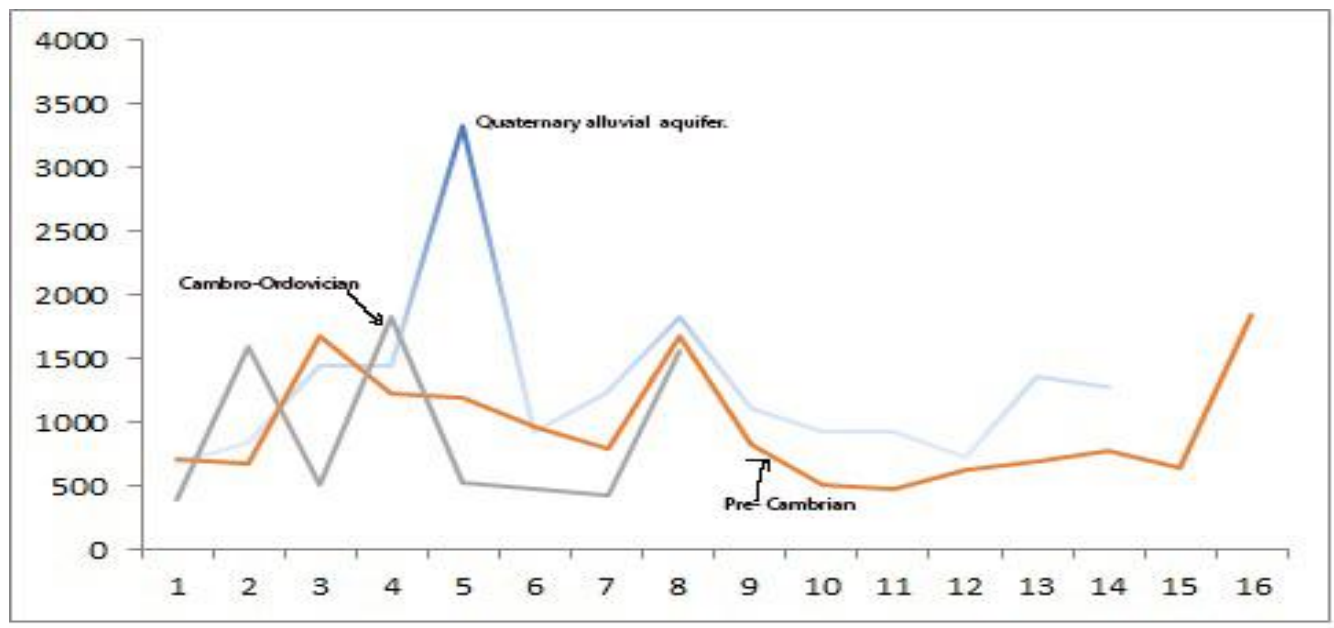

Fig. (26): Distribution of uranium in groundwater of the study area 


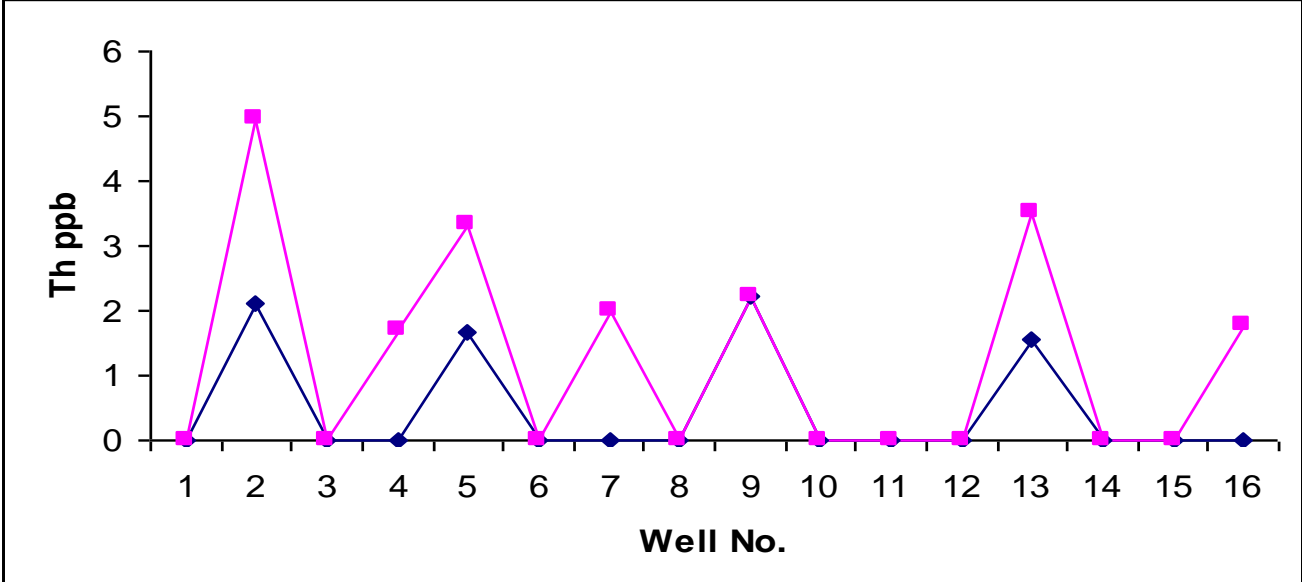

Fig (27): Distribution of thorium in groundwater of the study area

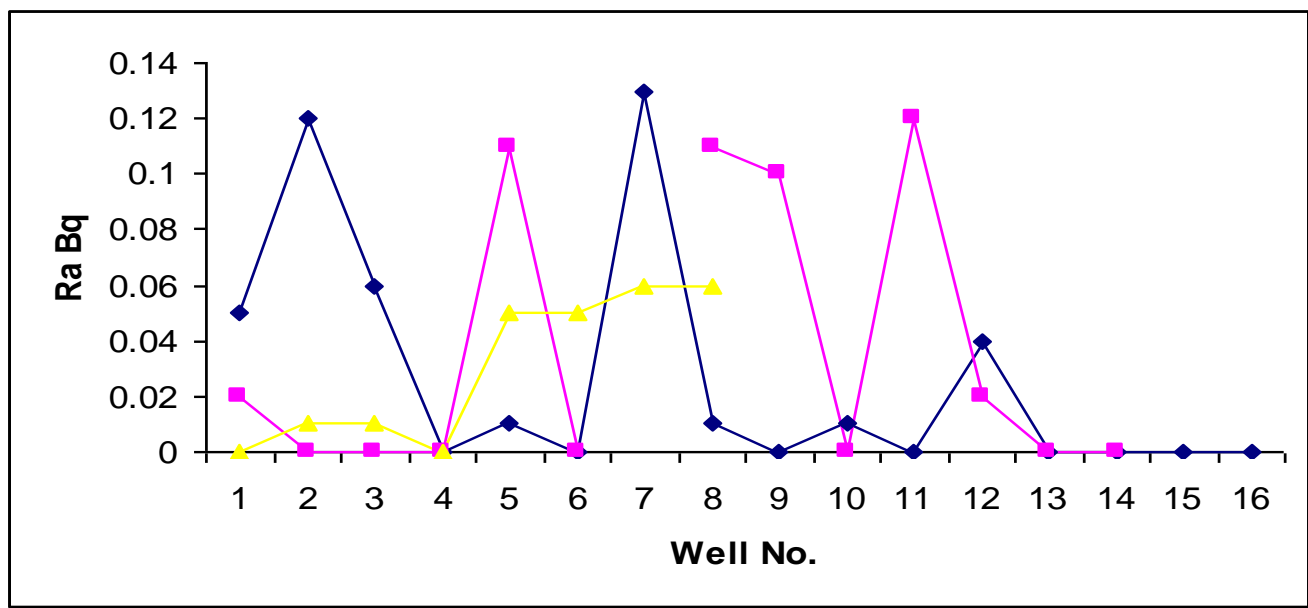

Fig. (28): Distribution of radium in groundwater of the study area (pci). 
دراسات هيدروجيوكيميائية واشعاعية على حوض بعيع- سدري جنوب غرب سيناء، مصر

عادل حسن 'الافندي، محمد حلمي` جريش، شحته ابو'فندود عويضة، عبدالله ' الثامي وخالد' عبدالحليم ا - - هيئة المواد النووية r ب- كلية العلوم - جامعة قناة السويس

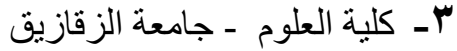

تقع منطقة الدراسة فى شرق مدينـة أبو زنيمـة. تمت الدراسـة من خـلال تجميع ^ب عينـة ميـاه مـن حوض بعبع - سدري، وقد تم إجراء جميع التحاليل الكيميائية (الكاتيونات ـ الانيونات) وقد وجد ان جميع النتائج اعلـي من المعدلات العالميـة بكثير،وهذا يؤكد العلاقة القويسة بين الســن الصـخرية وتأثير ها على المياه، كارتفاع مجموع الاملاح الأئبه وذلك نتيجة لوجود السبخات وتمعدنات الاملاح فى الصخور المحيطة بالخزانـات، وبنـاءا عليه تم معرفة الكاتيونـات والاتيونـات السـائده فى المياه. كذلك تـم عمـل تحاليل للعناصـر الارضية النـادرة مثل (النحساس - النيكلـ الرصـاص ـ الكوبلت ـ القصدير - الكادميوم ـ الحديد ـ المنجنيز)، وقد تبين من النتائج ان جميع التحاليل اعلي بكثير من المعدلات العالمية مما ترتب عليه تغيير الكثير من الخواص الفيزيائية والكيميائية للمياه وهذا مـا بـا واضـحا مـن خـلال دراسـة نوعيـة الميـاه مـن خـلال تطبيق بيبر وشـولر. كذلكك تـم دراسـة المحتوى الاشعاعى فى المياه الجوفيه وقد بينت الدراسة وجود تلوث اشعاعى بنسب عالية جدا تصل فى بعض

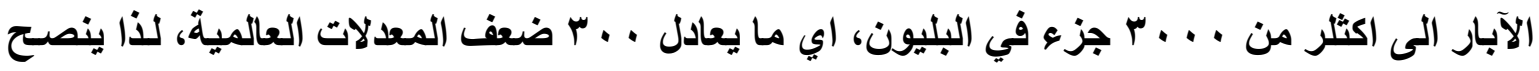
بعدم استخدام المياه وخاصة فى حوض بعبع لاى اغراض سواء آدميه او حيوانية. 